\title{
Morphological and molecular studies of Eudiplozoon nipponicum (Goto, 1891) and Eudiplozoon kamegaii sp. $\mathrm{n}$. (Monogenea; Diplozoidae)
}

\author{
Tomoki Nishihira ${ }^{1}$ and Misako Urabe ${ }^{2}$ \\ ${ }^{1}$ Division of Environmental Dynamics, Graduate School of Environmental Science, University of Shiga Prefecture, Hikone-City, Japan; \\ ${ }^{2}$ School of Environmental Science, The University of Shiga Prefecture, Hikone-City, Japan
}

\begin{abstract}
Eudiplozoon nipponicum (Goto, 1891) Khotenovsky, 1985 (Monogenea: Diplozoidae), is known to parasitise Cyprinus carpio Linnaeus and species of Carassius. In this study, we conducted a taxonomic re-examination of E. nipponicum using genetic analysis and morphological comparisons from different host species from a single water system. rDNA nucleotide sequences of the internal transcription spacer 2 (ITS-2) region (645 bp) showed interspecific-level genetic differences among diplozoids from species of Carassius and C. carpio (p-distance: $3.1-4.0 \%$ ) but no difference among those from different species of Carassius (0-0.4\%) or between those from C. carpio collected in Asia and Europe (0-1.1\%). Large variation was observed among 346 bp cytochrome $c$ oxidase subunit I (COI) sequences $(0.3-16.0 \%)$; the topology of the phylogenetic tree showed no relationship to host genera or geographical regions of origin. Morphological observation showed that average clamp size of diplozoids from C. carpio was larger than those from Carassius spp. The number of folds on the hindbody was 10-25 for diplozoids from C. carpio and 12-19 for those from Carassius spp. Thus, our ITS-2 sequence and morphological comparison results indicate that diplozoids from C. carpio and species of Carassius belong to different species. The scientific name E. nipponicum should be applied to the species infected to the type host, Carassius sp. of Nakabo (2013) (Japanese name ginbuna). The diplozoid infecting C. carpio (Eurasian type) should be established as a new species: Eudiplozoon kamegaii sp. n. A neotype of E. nipponicum is designated in this report because the original E. nipponicum specimens are thought to have been lost.
\end{abstract}

Keywords: genus Eudiplozoon, neotype, new species, host specificity, molecular phylogeny, morphology, monogenea

This article contains supporting information (S1) online at http://folia.paru.cas.cz/suppl/2020-67-018.pdf

Diplozoon nipponicum Goto, 1891 was described by Goto (1891) (Monogenea: Diplozoidae) based on specimens found on Carassius vulgaris (Nordmann) from Japan, but Goto (1891) designated neither the type specimens nor type locality. Khotenovsky (1981) later assigned this species to a new genus, Sindiplozoon Khotenovsky, 1981, followed by another new genus, Eudiplozoon Khotenovsky, 1985. Eudiplozoon nipponicum (Goto, 1891) is now the only species in the genus Eudiplozoon.

The type host $C$. vulgaris is now considered a synonym of Carassius carassius (Linnaeus) (Kottelat 1997). However, C. carassius is not distributed in Japan. Matejusová et al. (2001) misinterpreted the type host designated by Goto (1891) as C. carassius. Carassius vulgaris, as described by Goto (1891), may have been either Carassius sp. (Japanese name ginbuna) (Shimazu et al. 2015) or Carassius buergeri subsp. 2 (Japanese name kinbuna) (Nagasawa 2016).

In Japan, five species or subspecies of cyprinid fishes have been reported as natural hosts of E. nipponicum (sci- entific names follow Nakabo 2013): Cyprinus carpio Linnaeus (Japanese name koi) (Kamegai et al. 1966, Kamegai 1968, 1976, Ogawa 2010-2011), Carassius sp. (Japanese name ginbuna) (Kitahara et al. 1986, Hirose et al. 1987, Mizuo et al. 1999, Sicard et al. 2003), C. buergeri subsp. 2 (Japanese name kinbuna) (Kitahara et al. 1986, Sicard et al. 2003), Carassius buergeri grandoculis Temminck et Schlegel (Japanese name nigorobuna) (Kamegai 1975b, Ogawa 2010-2011), and Carassius cuvieri Temminck et Schlegel (Japanese name gengorobuna) (Kamegai 1977, Nagasawa 2016).

In other countries, the following fish species have been also recorded as hosts of E. nipponicum: Carassius auratus gibelio (Bloch) and Channa argus (Cantor) (Channidae) from China (Jiang et al. 1989, Jiang 2000, Gao et al. 2007), Cyprinus carpio rubrofuscus Lacépède, Abramis bra$m a$ (Linnaeus) (Cyprinidae), Capoeta capoeta heratensis (Keyserling) (Cyprinidae) and Luciobarbus capito conocephalus (Kessler) (Cyprinidae) from Russia (Pugachev et 


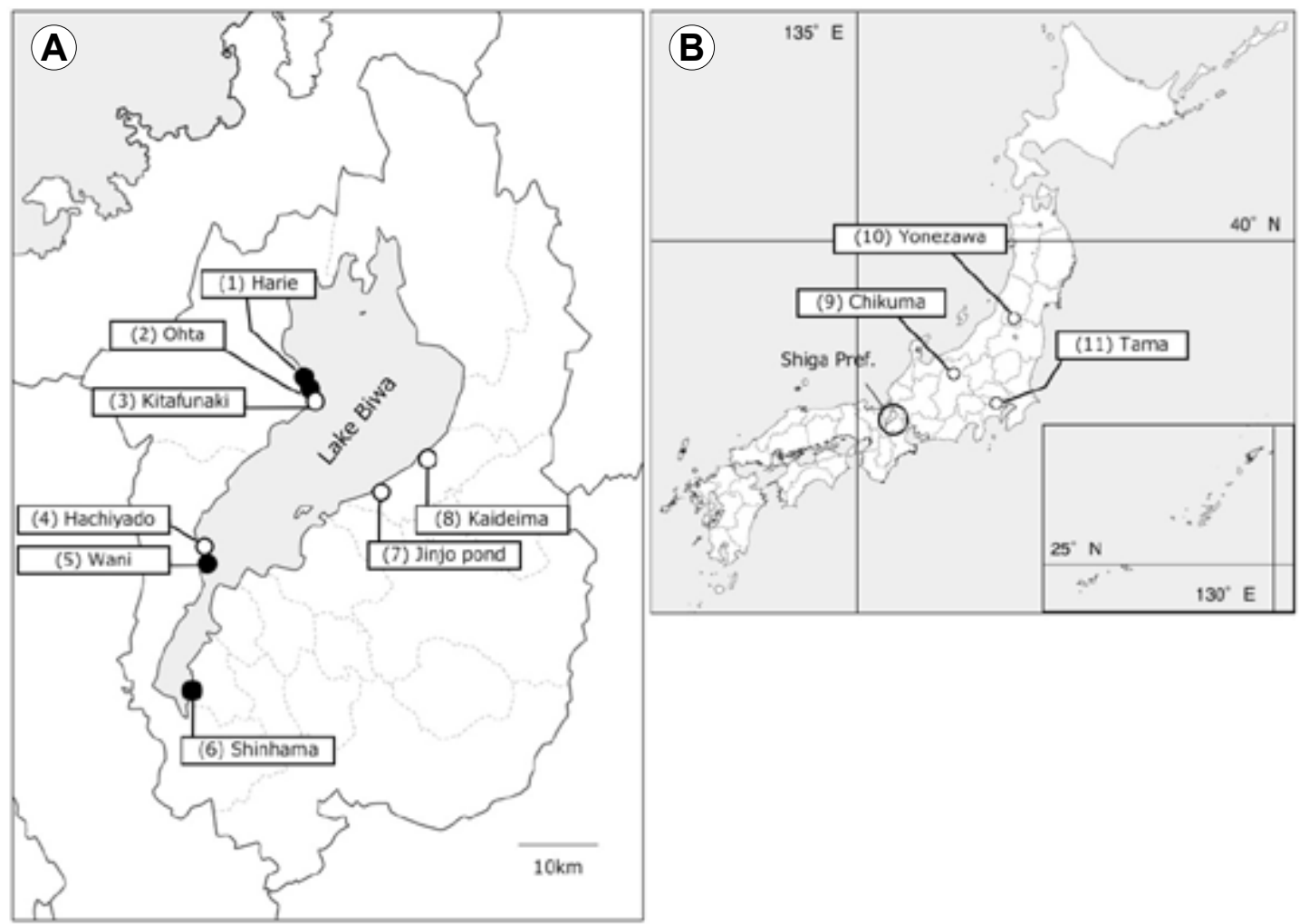

Fig. 1. Sampling localities of host fish. A - Shiga prefecture; B - out of Shiga. Black circle, localities where Eudiplozoon were collected; open circle, localities where Eudiplozoon were absent.

al. 2010), Leuciscus vorax (Heckel) (Cyprinidae) and Mesopotamichthys sharpeyi (Günther) (Cyprinidae) from Iraq (Al-Saadi et al. 2010, Mhaisen and Abdul-Ameer 2014).

Sicard et al. (2003) compared E. nipponicum obtained from C. carpio in France and Eudiplozoon sp. found on Carassius auratus (Linnaeus) (in fact Carassius sp. - Japanese name ginbuna; T. Shimazu personal communication) from Japan using the internal transcribed spacer 2 (ITS-2) rDNA region and found a genetic distance of 0.028 (Kimura's two-parameter model) between E. nipponicum and Eudiplozoon sp. This value was lower than the average interspecific distance (0.094) for the genus Paradiplozoon (Diplozoidae) (Sicard et al. 2003).

These authors suggested that the genetic distance between E. nipponicum from C. carpio in Europe and Eudiplozoon sp. from Carassus auratus in Japan supports the view that $E$. nipponicum should be divided into two species or subspecies. However, they did not analyse diplozoids from $C$. carpio in Japan and therefore could not determine whether this genetic difference was derived from host segregation or geographical distances (there are no records of E. nipponicum from Carassius in Europe). Sequence data for the diplozoids analysed by Sicard et al. (2003) have not been published.

Zhang et al. (2018) subsequently sequenced the complete mitogenome and ITS-2 region of Eudiplozoon sp. obtained from a $C$. auratus complex from Tangxun Lake, Hubei Province, China, and found a significant difference from E. nipponicum found on C. carpio from France (AY009163) in ITS-2 sequences (94-95\% of similarity) and COI sequence ( $83 \%$ of similarity). Their mitogenome sequence (MG458326) is the only sequence of Eudiplozoon from Carassius registered with the International Nucleotide Sequence Database. Zhang et al. (2018) suspected the existence of cryptic species of Eudiplozoon and discussed the need of taxonomic revision of the genus.

To resolve the problem of species composition of $E \mathbf{~}$ diplozoon is necessary to collect diplozoids from both C. carpio and sympatrically distributed species of Carassius and compare their morphology and DNA sequences. It is thought that all E. nipponicum specimens collected by Goto (1891) have already been lost (Shimazu and Araki 2006). Therefore, it is necessary to designate a neotype of E. nipponicum.

In this study, we compared the molecular and morphological characteristics of diplozoids found on C. carpio and species of Carassius captured in a single water system in Japan to clarify genetic and/or morphological divergences in diplozoids on different host genera that were not geologically isolated. We redescribed E. nipponicum with the designation of neotype and also described one new species.

\section{MATERIALS AND METHODS}

\section{Collection and identification of the host fishes}

We collected species of Carassius and Cyprinus carpio from 8 locations in Shiga Prefecture, Japan (1-8 in Table 1 and Fig. 1A). Specimens of Eudiplozoon were obtained from 4 localities of them: Harie (1), 20 pairs of adult diplozoids (40 individuals) and 1 diporpa from Carassius buergeri grandoculis; Ohta (2): 7 pairs of adult diplozoids (16 individuals) from C. buergeri grandoculis and 5 pairs of adult diplozoids ( 8 individuals) from Carassius 
Table 1. Sampling locality, sampling period and host species of diplozoids examined.

\begin{tabular}{|c|c|c|c|c|c|c|c|}
\hline Locality & Sampling period & Fish species examined & $\mathrm{n}$ & $\begin{array}{l}\text { range of the } \\
\text { standard } \\
\text { length }(\mathrm{cm})\end{array}$ & $\begin{array}{l}\text { No. of fish } \\
\text { infected }\end{array}$ & $\begin{array}{l}\text { No. of paird } \\
\text { diplozoids }\end{array}$ & $\begin{array}{l}\text { No. of } \\
\text { diporpae }\end{array}$ \\
\hline \multirow{4}{*}{$\begin{array}{l}\text { (1) Harie, Shin-asahi Town, } \\
\text { Takashima City, Shiga Prefecture } \\
\left(35^{\circ} 22^{\prime} 17^{\prime \prime N} \text {; } 136^{\circ} 02^{\prime} 47^{\prime \prime E}\right)\end{array}$} & \multirow{4}{*}{$\begin{array}{l}\text { May-August 2016, } \\
\text { May-November } 2017 \\
\text { and June } 2019\end{array}$} & $\begin{array}{l}\text { Carassius buergeri grandoculis } \\
\text { (nigoro-buna) }\end{array}$ & 68 & $11.7-32.9$ & 10 & 20 & 1 \\
\hline & & Carassius sp. (gin-buna) & 71 & $7.0-31.5$ & 0 & 0 & 0 \\
\hline & & Carassius spp. (not identfied) & 7 & $2.4-32.7$ & 0 & 0 & 0 \\
\hline & & Cyprinus carpio & 8 & $11.1-59.3$ & 0 & 0 & 0 \\
\hline \multirow{2}{*}{$\begin{array}{l}\text { (2) paddy field pond of Ohta } \\
\text { biotope, Shin-asahi Town, } \\
\text { Takashima City, Shiga Prefecture } \\
\left(35^{\circ} 20^{\prime} 24^{\prime \prime N} ; 136^{\circ} 04^{\prime} 13^{\prime \prime E}\right)\end{array}$} & \multirow{2}{*}{$\begin{array}{l}\text { May-November } 2018 \\
\text { and June } 2019\end{array}$} & Carassius buergeri grandoculis & 50 & $5.5-33.7$ & 5 & 7 & 0 \\
\hline & & Carassius sp. & 38 & $9.6-35.8$ & 4 & 5 & 0 \\
\hline \multirow{3}{*}{$\begin{array}{l}\text { (3) Kitafunaki, Adogawa Town, } \\
\text { Takashima City, Shiga Prefecture } \\
\left(35^{\circ} 19^{\prime} 59^{\prime \prime N} \text {; } 136^{\circ} 04^{\prime} 03^{\prime \prime E}\right)\end{array}$} & \multirow{3}{*}{ May 2016} & Carassius buergeri grandoculis & 9 & $8.3-14.9$ & 0 & 0 & 0 \\
\hline & & Carassius sp. & 6 & $8.8-24.8$ & 0 & 0 & 0 \\
\hline & & Carassius spp. (not identfied) & 1 & 11.6 & 0 & 0 & 0 \\
\hline $\begin{array}{l}\text { (4) shore net (eri) off the shore } \\
\text { of Lake Biwa at Hachiyado, }\end{array}$ & \multirow[b]{2}{*}{ June-August 2018} & Carassius buergeri grandoculis & 2 & $7.9-14.1$ & 0 & 0 & 0 \\
\hline $\begin{array}{l}\text { Otsu City, Shiga Prefecture } \\
\left(35^{\circ} 10^{\prime} 53^{\prime \prime N} ; 135^{\circ} 55^{\prime} 10^{\prime \prime} \mathrm{E}\right) \text { in } \\
\text { February } 2017\end{array}$ & & Carassius sp. & 5 & $8.3-13.6$ & 0 & 0 & 0 \\
\hline $\begin{array}{l}\text { (5)Wani fisheries port, Otsu City, } \\
\text { Shiga Prefecture }\left(35^{\circ} 09^{\prime} 55^{\prime \prime} \mathrm{N} \text {; }\right. \\
\left.135^{\circ} 55^{\prime} 26^{\prime \prime} \mathrm{E}\right)\end{array}$ & February 2017 & Cyprinus carpio & 1 & 34.4 & 1 & 2 & 0 \\
\hline $\begin{array}{l}\text { (6) biotope on the coast of Lake } \\
\text { Biwa at Shinhama, Kusatsu City, }\end{array}$ & November 2017 and & Carassius sp. & 6 & $10.8-32.7$ & 0 & 0 & 0 \\
\hline $\begin{array}{l}\text { Shiga Prefecture }\left(34^{\circ} 59^{\prime} 52^{\prime \prime N}\right. \\
\left.135^{\circ} 54^{\prime} 30^{\prime \prime E}\right)\end{array}$ & $\begin{array}{l}\text { August-November } \\
2018\end{array}$ & Cyprinus carpio & 10 & $9.0-17.9$ & 5 & 8 & 2 \\
\hline \multirow{3}{*}{$\begin{array}{l}\text { (7) Jinjo pond, Satsuma, } \\
\text { Hikone City, Shiga Prefecture } \\
\left(35^{\circ} 13^{\prime} 44^{\prime \prime N} ; 136^{\circ} 09^{\prime} 37^{\prime \prime E}\right)\end{array}$} & \multirow{3}{*}{ August 2018} & Carassius buergeri grandoculis & 1 & 5.1 & 0 & 0 & 0 \\
\hline & & Carassius sp. & 4 & $6.4-8.0$ & 0 & 0 & 0 \\
\hline & & Carassius cuvieri (gengoro-buna) & 2 & $11.1-14.7$ & 0 & 0 & 0 \\
\hline $\begin{array}{l}\text { (8) Kaideima Bridge, Kaideima, } \\
\text { Hikone City, Shiga Prefecture } \\
\left(35^{\circ} 15^{\prime} 23^{\prime \prime N} \text {; } 136^{\circ} 13^{\prime} 39^{\prime \prime} \mathrm{E}\right)\end{array}$ & June 2018 & Carassius buergeri grandoculis & 1 & 21.3 & 0 & 0 & 0 \\
\hline $\begin{array}{l}\text { (9) Chikuma River, Senbonyanagi, } \\
\text { Chikuma City, Nagano Prefecture } \\
\left(36^{\circ} 29^{\prime} 59^{\prime \prime} \text {; } 138^{\circ} 08^{\prime} 01^{\prime E}\right)\end{array}$ & May 2016 & Carassius sp. & 10 & $7.1-12.8$ & 0 & 0 & 0 \\
\hline $\begin{array}{l}\text { (10) Tanjo River, Hirohata } \\
\text { Town, Yonezawa City, Yamagata } \\
\text { Prefecture }\left(37^{\circ} 56^{\prime} 47^{\prime \prime N} \text {; }\right. \\
\left.140^{\circ} 04^{\prime} 13^{\prime \prime E}\right)\end{array}$ & August 2016 & $\begin{array}{l}\text { Carassius buergeri subsp. } 2 \\
\text { (kin-buna) }\end{array}$ & 17 & $3.8-9.8$ & 0 & 0 & 0 \\
\hline $\begin{array}{l}\text { (11) Ichinomiya, Tama City, Tokyo } \\
\text { Metropolitan area }\left(35^{\circ} 39^{\prime} 16^{\prime \prime N} ;\right. \\
\left.139^{\circ} 26^{\prime} 21^{\prime \prime E}\right)\end{array}$ & September 2017 & Carassius sp. & 10 & $2.8-6.6$ & 0 & 0 & 0 \\
\hline
\end{tabular}

sp.; Wani (5): 2 pairs of adult diplozoids (four individuals) from Cyprinus carpio; and Shinhama (6): 8 pairs of adult diplozoids (16 individuals) from C. carpio. We also examined fishes from 3 sites out of Shiga Prefecture, but none of them was infected with diplozoids (9-11 in Table 1 and Fig. 1B).

Collected fish were brought to the laboratory and kept in a water tank until dissection. Fish that were dead or weak at the time of collection were brought back to the laboratory on ice and dissected immediately. Their gills were excised and placed in Petri dishes with $0.4 \%$ saline, and diplozoids on the gills were identified under a stereoscopic microscope. Detected diplozoids were placed on glass slides, and a small piece of the forebody was cut for DNA analyses. These pieces were stored at $-18^{\circ} \mathrm{C}$ until DNA analyses. Remaining worm bodies were fixed and stained for morphological study (see bellow).

Fish samples were photographed for morphological identification and standart length (SL) was measured before dissection. Among Carassius species, body height ratio (SL/body height), number of branched soft rays on the dorsal fin and number of gill rakers were measured for species identification (Miyaji et al. 1976, Nakabo 2013). When the sample fish could not be identified by morphology, the blood cell diameter were measured to distinguish Carassius sp. (triploids) from other diploid species (Fujiwara and Usuki 1994, Kohashi 1994). However, this method was not applied in the early period of the study and some fish remained unidentified to the species level.

Two types of $C$. carpio are distributed in Japan: the Eurasian type, derived from individuals introduced from the Eurasian continent, and the native type, which was naturally distributed in prehistoric times (Mabuchi et al. 2005, Miyamoto and Nakajima 2006, Mabuchi et al. 2008, 2010). When diplozoids were detected from C. carpio, the host fish type was distinguished using a simplified molecular identification technique (Mabuchi and Nishida 2006). Fish DNA was extracted from a piece of muscle using the Wizard SV Genomic DNA Purification System (Promega, Madison, WI). A partial sequence of the cytochrome-b (Cyt-b) region of the mitochondrial DNA (mtDNA) was amplified via polymerase chain reaction (PCR), following the protocol by Mabuchi and Nishida (2006). PCR products were subjected to electrophoresis with 10 x Midori Green Direct (Nippon Genetics Co., Ltd., Tokyo, Japan), and amplified DNA fragment lengths were verified (ca. 400 and $280 \mathrm{bp}$ for the Eurasian and native types, respectively; Mabuchi and Nishida 2006).

\section{Molecular analysis}

Genomic DNA was extracted from frozen tissue samples using a Wizard SV Genomic DNA Purification System (Promega, Madison, Wisconsin, USA). In all newly obtained samples, partial regions of the ITS-2 from rDNA were amplified by PCR; 
Table 2. P-distance of the sequences of ITS-2 (645 bp) and COI (346 bp) between samples of Eudiplozoon Khotenovsky, 1985 obtained in the present study and data from DNA Data Bank of Japan, and Inustiatus spp. and Sindiplozoon ctenopharhyngodoni (outgroups). The maximum, minimum and the average (in parentheses) values are shown.

\begin{tabular}{|c|c|c|c|c|c|c|c|}
\hline \multirow{2}{*}{ species } & \multirow{2}{*}{ host } & \multirow{2}{*}{$\mathrm{n}$} & \multirow{2}{*}{$\begin{array}{c}\text { E. nipponicum } \\
\begin{array}{c}\text { Carassius buergeri } \\
\text { grandoculis }\end{array}\end{array}$} & \multirow{2}{*}{$\begin{array}{l}\text { E. nipponicum } \\
\text { Carassius sp. }\end{array}$} & \multirow{2}{*}{$\begin{array}{l}\text { Eudiplozoon sp.* } \\
\text { Carassius auratus }\end{array}$} & \multirow{2}{*}{$\begin{array}{l}\text { E. kamegaii sp. } \mathrm{n} . \\
\text { Cyprinus carpio } \\
\text { Eurasian type }\end{array}$} & \multirow{2}{*}{$\begin{array}{c}\begin{array}{c}\text { E. nipponicum* } \\
(=\text { E. kamegaii })\end{array} \\
\text { Cyprinus carpio }\end{array}$} \\
\hline & & & & & & & \\
\hline \multicolumn{8}{|l|}{ ITS-2 } \\
\hline Eudiplozoon japonicum & $\begin{array}{l}\text { Carassius buergeri } \\
\text { grandoculis }\end{array}$ & 15 & $0.0-0.5(0.1)$ & & & & \\
\hline Eudiplozoon japonicum & Carassius sp. & 2 & $0.0-0.4(0.1)$ & 0,0 & & & \\
\hline $\begin{array}{l}\text { Eudiplozoon kamegaii } \\
\text { n.sp. }\end{array}$ & $\begin{array}{l}\text { Cyprinus carpio } \\
\text { Eurasian type }\end{array}$ & 11 & $3.1-4.0(3.2)$ & $3.1-3.6(3.2)$ & & $0.0-0.7(0.3)$ & \\
\hline $\begin{array}{l}\text { Eudoplozoon } \\
\text { nipponicum* } \\
\text { (=E. kamegaii) } \\
\text { (outgroups) }\end{array}$ & Cyprinus carpio & 6 & $3.1-3.8(3.2)$ & $3.1-3.4(3.2)$ & & $0.0-1.1(0.3)$ & $0.0-0.4(0.2)$ \\
\hline $\begin{array}{l}\text { Sindiplozoon } \\
\text { ctenopharyngodoni* }\end{array}$ & $\begin{array}{l}\text { Ctenopharyngodon } \\
\text { idella }\end{array}$ & 1 & $23.2-23.6(23.4)$ & 23.4 & & $23.9-24.5(24.1)$ & $23.9-24.3(24.0)$ \\
\hline $\begin{array}{l}\text { Inustiatus inustiatus, } \\
\text { I. aristichthysi* }\end{array}$ & $\begin{array}{l}\text { Hypophthalmichthys } \\
\text { molitrix, Aristichthys } \\
\text { nobilis }\end{array}$ & 2 & $26.1-26.4(26.2)$ & 26.3 & & $27.2-27.5(27.2)$ & $27.2-27.5(27.3)$ \\
\hline \multicolumn{8}{|l|}{ COI } \\
\hline Eudiplozoon japonicum & $\begin{array}{l}\text { Carassius buergeri } \\
\text { grandoculis }\end{array}$ & 3 & $0.6-14.9(9.9)$ & & & & \\
\hline Eudiplozoon sp.* & Carassius auratus & 1 & $10.5-16.0(14.2)$ & & & & \\
\hline $\begin{array}{l}\text { Eudiplozoon kamegaii } \\
\text { sp.n. }\end{array}$ & $\begin{array}{l}\text { Cyprinus carpio } \\
\text { Eurasian type }\end{array}$ & 2 & $0.3-15.2(10.3)$ & & $9.3-10.8(10.1)$ & 2.6 & \\
\hline $\begin{array}{l}\text { Eudoplozoon } \\
\text { nipponicum* } \\
\text { (=E. kamegaii) } \\
\text { (outgroup) }\end{array}$ & Cyprinus carpio & 1 & $2.3-13.7(6.1)$ & & 16.0 & $13.7-14.0(13.8)$ & \\
\hline Sindiplozoon sp.* & $\begin{array}{l}\text { Mylopharyngodon } \\
\text { piceus, Parabramis } \\
\text { pekinensis, } \\
\text { Spinibarbus hollandi }\end{array}$ & 1 & $19.2-20.1(19.7)$ & & 18.1 & $19.2-19.5(19.4)$ & 19.2 \\
\hline
\end{tabular}

in a subset of samples, partial regions of cytochrome $c$ oxidase subunit I gene (COI) from mtDNA were also amplified. PCR was performed in $20 \mu 1$ reaction mixture containing $13.8 \mu 1$ pure water, $2.0 \mu 110 \times \mathrm{Ex}$ Taq Buffer (Takara Bio Inc., Shiga, Japan), $1.6 \mu \mathrm{l}$ dNTP Mixture (Takara Bio Inc.), $1.0 \mu \mathrm{l}$ each of forward and reverse primers, $0.1 \mu 1 \mathrm{Ex}$ Taq (Takara Bio Inc.) and $0.5 \mu \mathrm{l}$ template DNA.

To amplify the ITS-2 region, we used the $3 \mathrm{~S}\left(5^{\prime}-\mathrm{GGT}\right.$ ACC GGT GGA TCA CTC GGC TCG-3') and BD2 (5'-TAT GCT TAA RTT CAG CGG GT-3') primer set (Bowles et al. 1995). To amplify the COI regions, we used the EuDiploCO1-longF (5'GGT TTT GTT TAT TTA YTT ATG GG-3') (originally designed) and ASmit2 (5'-TAA AGA AAG AAC ATA ATG AAA ATG-3') (Littlewood et al. 1997) primers. We also used the EuDiploCOI-F (5'-ATG TTT CAG CAT ATG TTT TGR TTT-3') and EuDiploCOI-R2 (5'-AAA YCA AAA CAT ATG CTG AAA CAT-3') internal primers when necessary.

The thermocycling profile was as follows: $94^{\circ} \mathrm{C}$ at $30 \mathrm{~s}, 40$ cycles of $94^{\circ} \mathrm{C}$ for $10 \mathrm{~s}, 50^{\circ} \mathrm{C}$ for $30 \mathrm{~s}, 72^{\circ} \mathrm{C}$ for $60 \mathrm{~s}$. Then DNA fragments were extended at $72^{\circ} \mathrm{C}$ for $7 \mathrm{~min}$, and stored at $4^{\circ} \mathrm{C}$. PCR was performed using a 2720 Thermal Cycler (Applied Biosystems, Life Technologies Co., Carlsbad, California, USA).

PCR products were cleaned using Wizard SV Gel and PCR Clean-up System (Promega) and sequenced directly by FASMAC Co. (Kanagawa, Japan). Then, analysed sequences were registered in the DNA Data Bank of Japan (DDBJ; accession nos.
LC496174-LC496190 and LC517162-LC517172 for ITS-2 and LC517173-LC517177 for COI).

Sequences were aligned with those of Eudiplozoon registered in DDBJ (Supplementary Table 1) using the ClustalW with the default parameters. A total of 645 positions were included for ITS-2 analysis and 346 positions for COI analysis. A maximum likelihood (ML) tree was constructed using the MEGA7.0.20 (Kumar et al. 2016). Probabilities were tested via bootstrap analyses of 1,000 replicates. Prior to ML analyses, a DNA substitution model was selected using neighbor-joining trees; the $\mathrm{NT}+\mathrm{G}$ model was selected for ITS-2 and applied for phylogenetic analyses with a default gamma parameter of 5 . The HKY + I model was selected for COI analyses. Sindiplozoon ctenopharyngodoni (Ling, 1973) (DQ098898), Inustiatus inustiatus (Nagibina, 1965) (DQ098893) and I. aristichthysi (Ling, 1973) (DQ098894) were used as ITS-2 outgroups, and Sindiplozoon sp. (MG458326) was used as an outgroup for COI tree construction. We also calculated p-distances between samples for each of ITS-2 and COI.

\section{Morphological study}

Each worm body was slightly pressed between a glass slide and cover slip, fixed in alcohol formal acetic acid (AFA), stained with Heidenhain's iron hematoxylin following the standard protocol, serially dehydrated in ethanol, cleared in creosote, followed by xylene, and mounted in Canada balsam. 


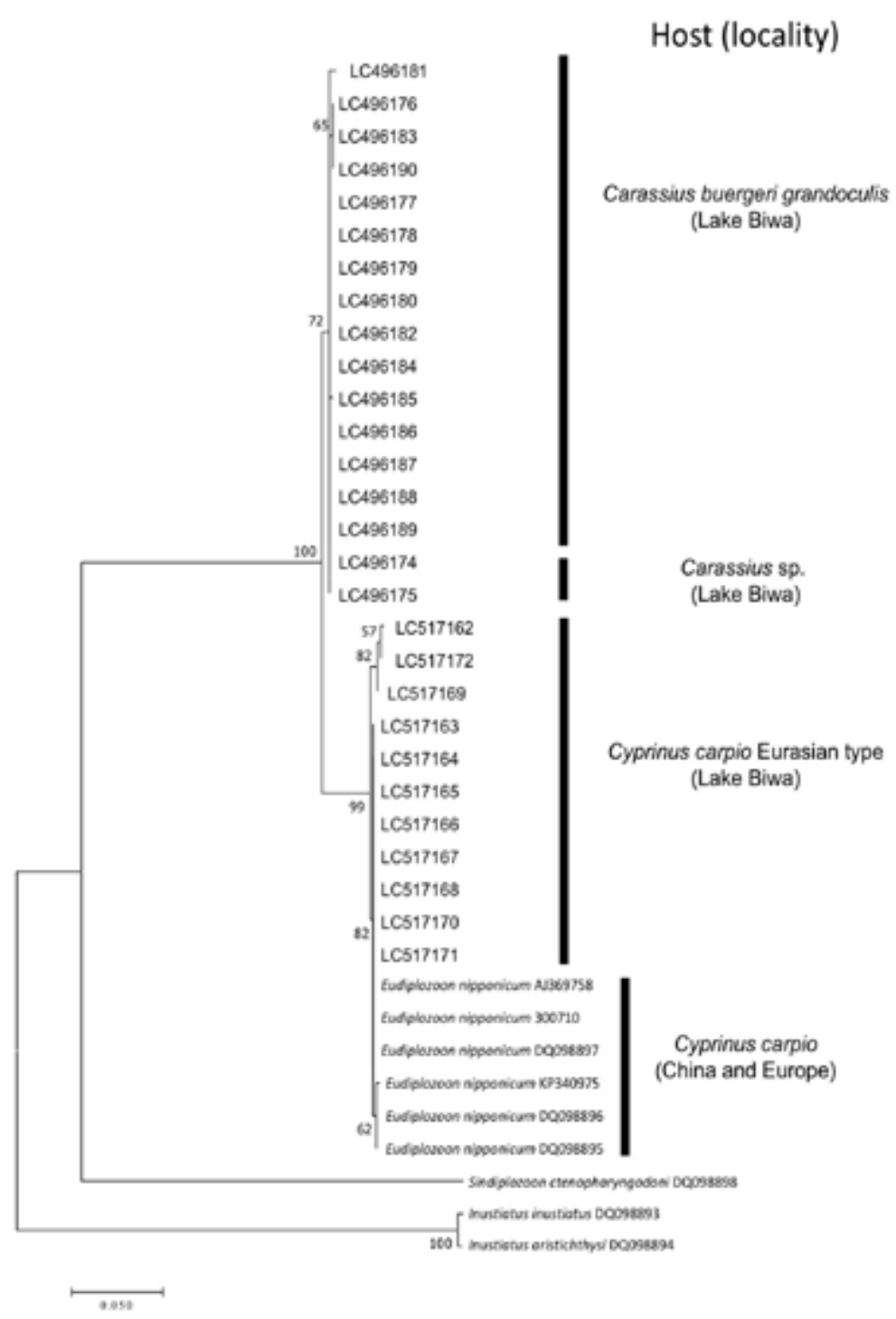

Fig. 2. Maximum-likelihood phylogenetic tree of diplozoids based on partial sequences of the ITS-2 (645 bp).

The mounted specimens were observed under a biological microscope and drawings were made with the aid of a camera lucida. Body length was measured from photographs of mounted specimens, using the Image J (v. 1.51j8) software. Inner organs were measured using a digital camera at the microscope setting, with the WraySpect (Ver. 2.) software. The number of folds on the hindbody was also counted under a microscope. These measurement sites followed those of Khotenovsky (1985). Posterior to anterior clamps on haptor were numbered as I-IV, following Hirose et al. (1987). Measurements of juveniles (paired immature individuals) and diporpae were excluded from the statistical anayses. A portion of specimens used in the present study were deposited at the National Museum of Nature and Science, Tokyo, Japan (NMNS) and Institute of Parasitology, Biology Centre of the Czech Academy of Science, České Budějovice, Czech Republic (IPCAS).

We also measured many Eudiplozoon specimens deposited in Meguro Parasitological Museum, Tokyo (MPM), prepared by Satoru Kamegai and his collaborators from 1965 to 1980 (Supplementary Table 2). Fourteen pairs of Eudiplozoon specimens from Carassius sp., 42 pairs from C. buergeri subsp. 2, and 15 pairs from Cyprinus carpio (type unknown) were measured for clamp size, and 25 pairs from Carassius sp., 35 pairs from C. buergeri subsp. 2, 5 pairs from unidentified Carassius spp. and 49 pairs from $C$. carpio (type unknown) were measured for the number of folds on the hindbody, to confirm whether they share morphological characteristics with new specimens obtained from host fishes of the same genera (Carassius or Cyprinus).

\section{RESULTS}

Diplozoid prevalence and intensity in collected fish

We collected 150 specimens of Carassius sp. (6.4-35.8 $\mathrm{cm} \mathrm{SL}), 131$ C. buergeri grandoculis (5.5-33.7 cm SL), 17 C. buergeri subsp. 2 (3.8-9.8 cm SL), 2 C. cuvieri (11.1$14.7 \mathrm{~cm} \mathrm{SL}), 8$ unidentified Carassius spp. (2.4-32.7 cm SL) and 19 Cyprinus carpio (9.0-59.3 cm SL) (Table 1). A total of 42 paired diplozoids and 3 diporpae were obtained: 5 pairs from Carassius sp., 27 pairs and 1 diporpa from C. buergeri grandoculis, 10 pairs and 2 diporpae from C. carpio. The prevalence of diplozoid infection around Lake Biwa was 3.1\% (4/130) among Carassius sp., 11.5\% (15/130) among C. buergeri grandoculis, and 31.6\% (6/19) 


\section{Host (locality)}

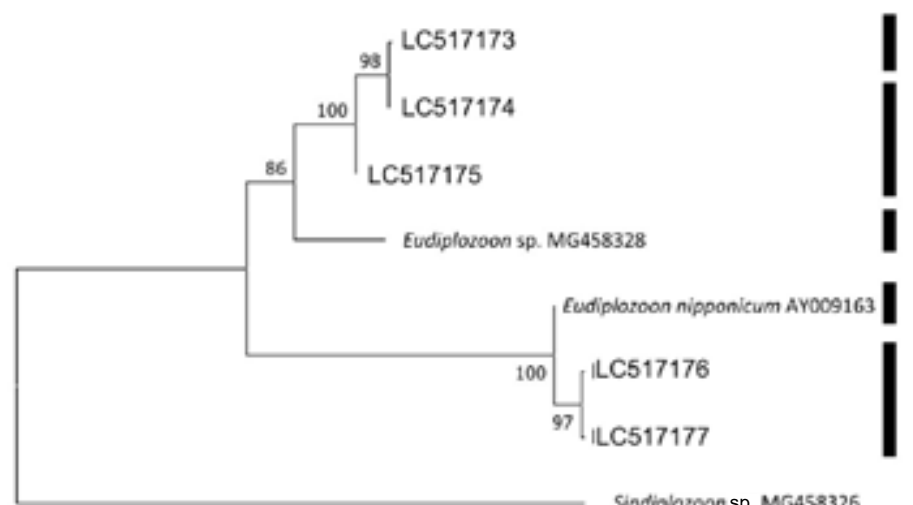

Carassius buergeri grandoculis (Lake Biwa)

Cyprinus carpio Eurasian type (Lake Biwa)

Carassius auratus (China)

Cyprinus carpio (France)

Carassius buergeri grandoculis (Lake Biwa)

Fig. 3. Maximum-likelihood phylogenetic tree of diplozoids based on partial sequences of the COI (346 bp).

A
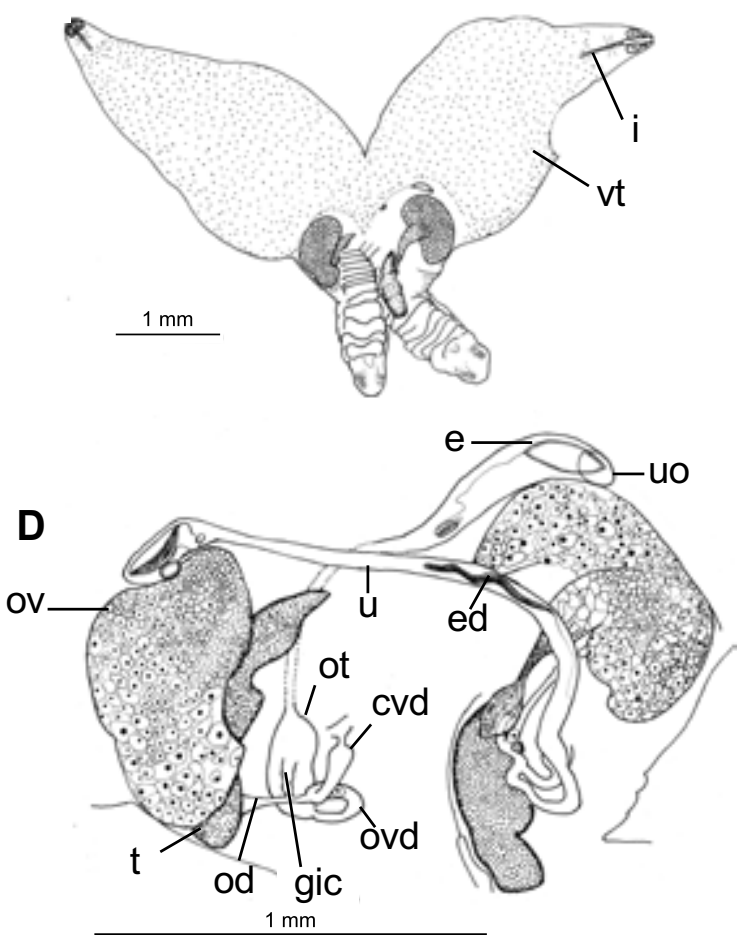

B

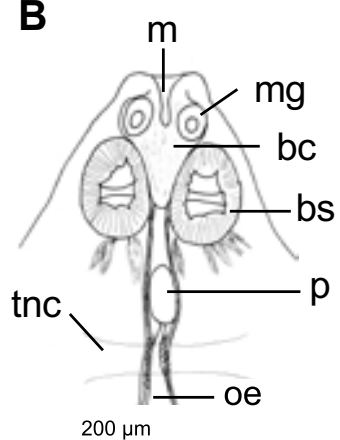

E

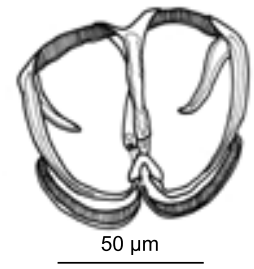

C

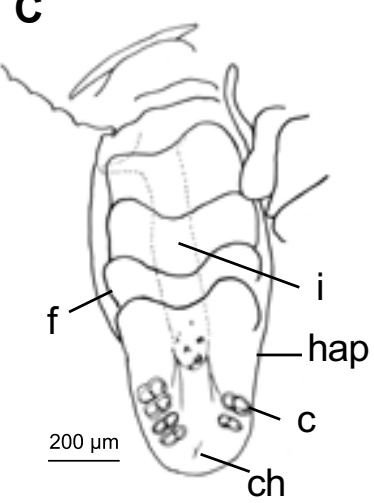

F $\quad \mathbf{G}$

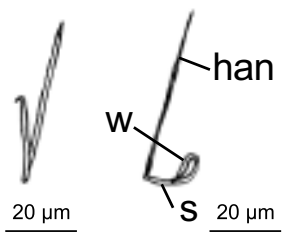

Fig. 4. Eudiplozoon nipponicum (Goto, 1891) Khotenovsky, 1985, neotype (NSMT-P1 6408). A - entire paired adults; B - anterior part of body, ventral view; C - posterior part of body, ventral view; D - reproductive organs; $\mathbf{E}$ - clamp I of a reference specimen (Urabe, personal collection); $\mathbf{F}$ - central hook; $\mathbf{G}$ - central hook of a reference specimen (NSMT-Pl 6410) (F and G bar $20 \mu \mathrm{m}$ ). Abbreviations: bc - buccal cavity; bs - buccal sucker; c - clamp; ch - central hook; cvd - common vitelline duct; e - egg; ed - egg deformed; f - fold; gic - genitointestinal canal; han - handle; hap - haptor; i - intestine; $\mathrm{m}$ - mouth; $\mathrm{mg}$ - musculo-glandular organs; od - oviduct; oe - oesophagus; ot - ootype; ov - ovary; ovd - ovovitelline duct; $\mathrm{p}$ - pharynx; $\mathrm{s}$ - shaft of hook; $\mathrm{t}$ - testis; tnc - transverse nerve commissure; $\mathrm{u}$ - uterus; uo - uterus opening; vt - vitelline follicles; w - wing of hook.

among C. carpio. No diplozoids were detected from C. cuvieri or unidentified species of Carassius. The mean intensities were 2.5 in Carassius sp. (paired diplozoids were counted as 2 individuals), 3.9 in C. buergeri grandoculis, and 3.7 in C. carpio.

\section{Molecular analysis}

We successfully sequenced 28 samples (10 pairs and 1 diporpa from Cyprinus carpio, 2 pairs from Carassius sp., 14 pairs and 1 diporpa from C. buergeri grandoculis). Following the simplified molecular identification, all six C. carpio harbouring diplozoids were classified as the Eurasian type.

Diplozoids from C. carpio, including sequences obtained in the present study and from DDBJ, and those from species of Carassius were separated into different clades in the ML tree based on the 645 bp ITS- 2 region (Fig. 2). The p-distance between diplozoids from differ- 
A

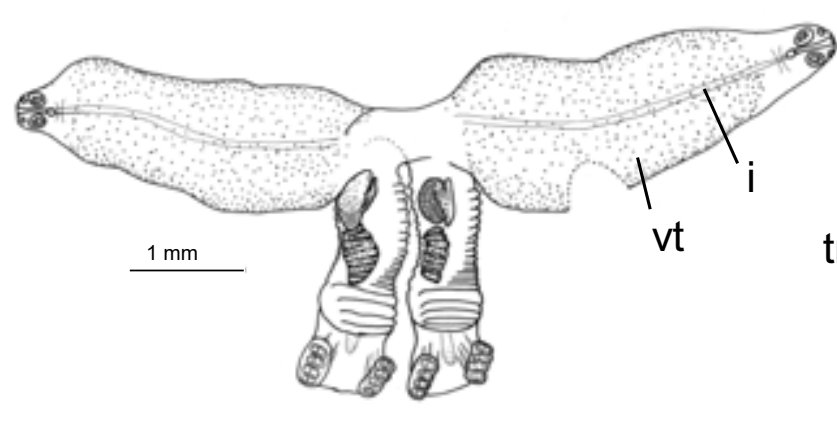

B

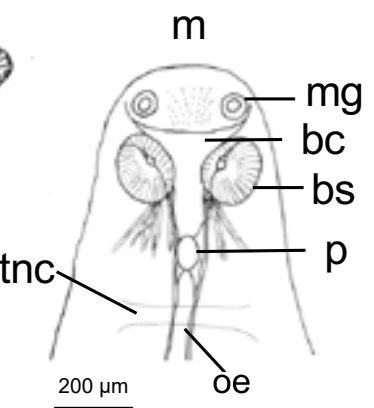

$500 \mu \mathrm{m}$

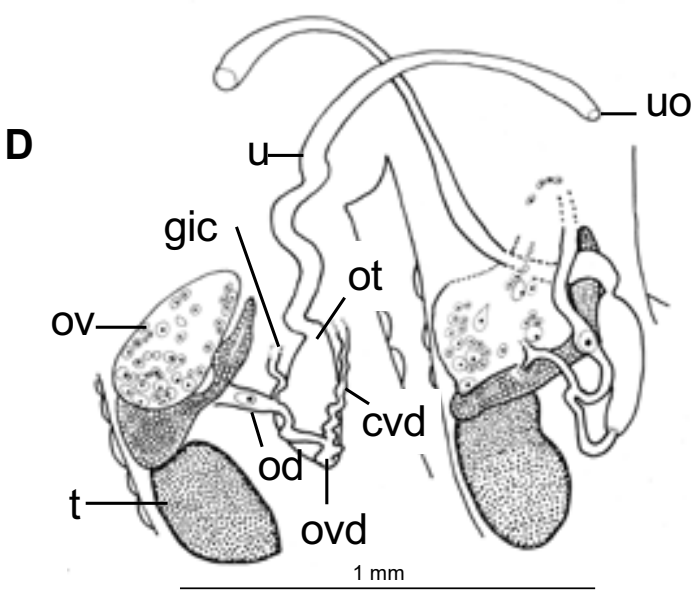

$\mathbf{E}$

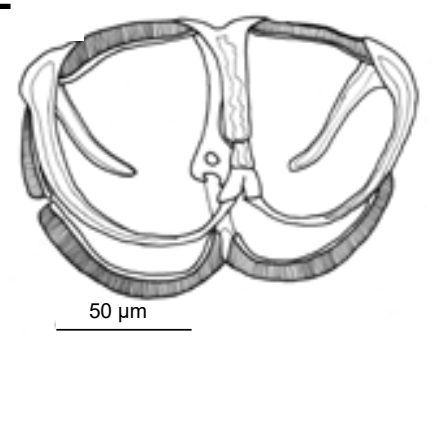

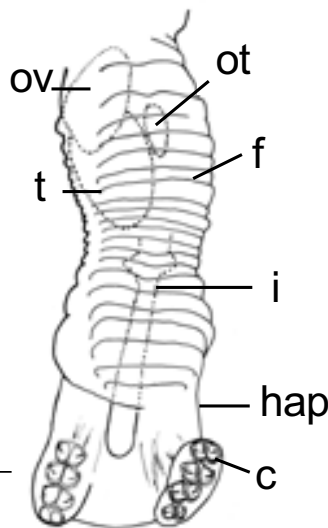

$\mathbf{F}$

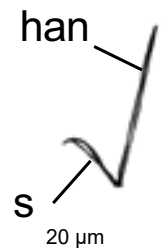

Fig. 5. Eudiplozoon kamegaii sp. n. A - holotype (NSMT-PL 6405); B - anterior part of body, ventral view; C - posterior part of body, ventral view; D - reproductive organs; E - clamp II; F - central hook. Abbreviations: bc - buccal cavity; bs - buccal sucker; c clamp; cvd - common vitelline duct; f - fold; gic - genitointestinal canal; mg - musculo-glandular organs; han - handle; hap - haptor; $\mathrm{i}$ - intestine; $\mathrm{m}$ - mouth; oe - oesophagus; ot - ootype; ov - ovary; ovd - ovovitelline duct; $\mathrm{p}$ - pharynx; $\mathrm{s}$ - shaft of hook; $\mathrm{t}$ - testis; tnc - transverse nerve commissure; $\mathrm{u}$ - uterus; uo - uterus opening; $\mathrm{vt}$ - vitelline follicles.

ent host genera were $3.1-4.0 \%$ (Table 2). Eight of eleven diplozoid sequences newly obtained from C. carpio (Eurasian type) were coincided with those of Eudiplozoon nipponicum from C. carpio in the Czech Republic and China (AJ300710 and DQ098897, respectively). Among the remaining three samples, 1-4 bases were substituted. The p-distances among diplozoids from Carassius species, including Carassius sp. and C. buergeri grandoculis, were $0-0.5 \%$ (Table 2), and the same sequences were shared between diplozoids from Carassius sp. and some diplozoids from C. buergeri grandoculis.

The ML tree based on COI (346 bp) showed large variation among sequences, with neither samples from the same host species nor from the same locality forming a single clade (Fig. 3). The p-distances of COI sequences between samples of Eudiplozoon were relatively large (reaching $16.0 \%$ ) and there was large variation even between samples from C. buergeri grandoculis obtained from the Lake Biwa water system (Table 2). Two of three sequences obtained from diplozoids from $C$. buergeri grandoculis were similar and formed one clade with E. nipponicum from C. carpio in France. However, the remaining sequence was similar to those of diplozoids from C. carpio (Eurasian type) in the Lake Biwa water system, and forming one clade with Eudiplozoon sp. from China (Fig. 3).

\section{Morphological comparison between specimens of Eudiplozoon from different host species}

In all specimens obtained in this study, musculo-glandular organs were present anterior to buccal suckers and prominent folds were present on the hindbody. In addition, an egg filament was attached on the egg surface at the opposite end of the uterus opening among all seven gravid specimens. Therefore, all specimens were identified as belonging to the genus Eudiplozoon (Figs. 4, 5).

We focused on the number of folds on the hindbody and the clamp size as key characters for the distinction of diplozoids from C. carpio and species of Carassius. Diplozoids from Carassius sp. have 16-18 folds (median $17 ; \mathrm{n}=2$ ). Diplozoids from C. buergeri grandoculis have 14-17 folds (15.5; $\mathrm{n}=8)$. Diplozoids from $C$. carpio have $16-25$ folds $(21 ; n=17)$. MPM specimens from species of Carassius (including Carassius sp., C. buergeri subsp. 2 and unidentified fishes) have $12-19$ folds $(15 ; \mathrm{n}=102)$, and those from C. carpio have $10-23$ folds $(18 ; \mathrm{n}=80)$.

Figures $4 \mathrm{E}$ and $5 \mathrm{E}$ show the clamp morphology of diplozoids from C. buergeri grandoculis and from C. carpio. Diplozoids from both host genera have clamps with a small projection at the anterior end of median sclerite, followed by a V-shaped sclerite, connecting with anterior clamp jaws. Additional thin projection, a ligament-like 
A

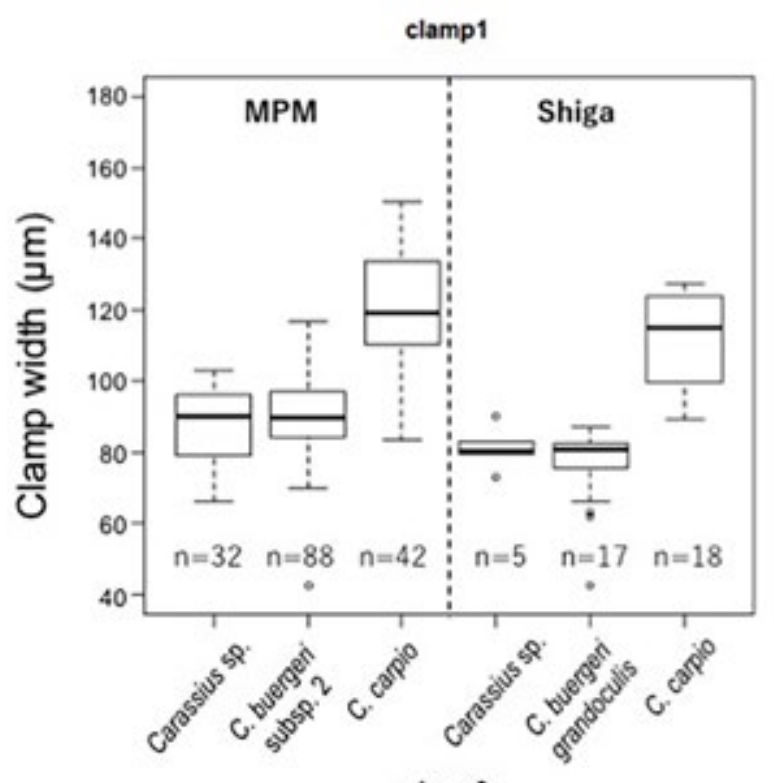

C

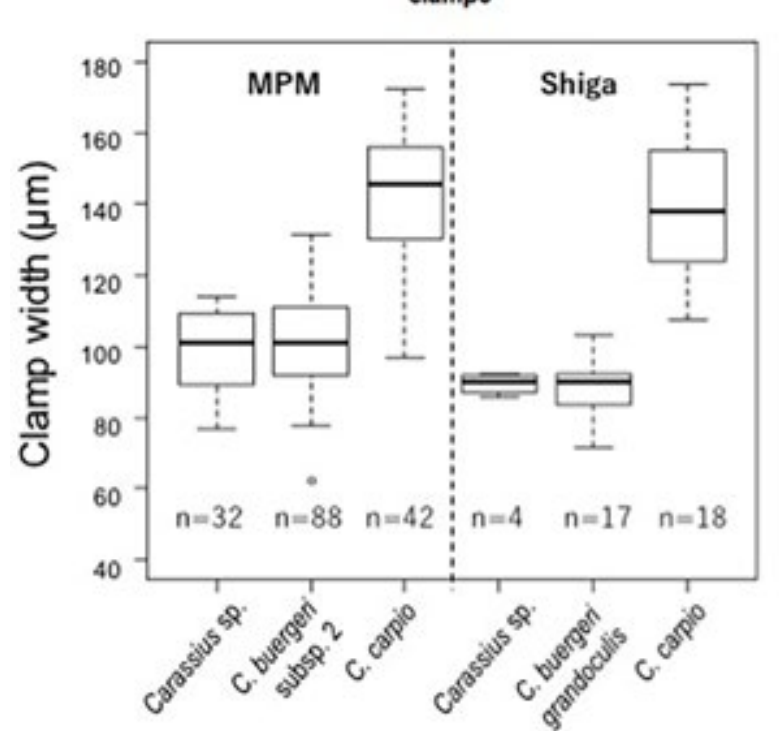

B

clamp2

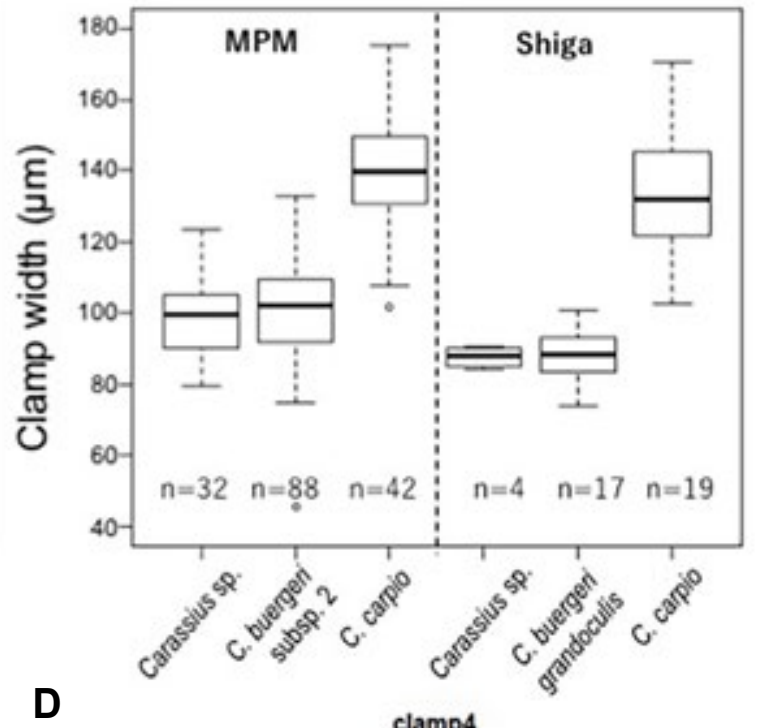

clamp4

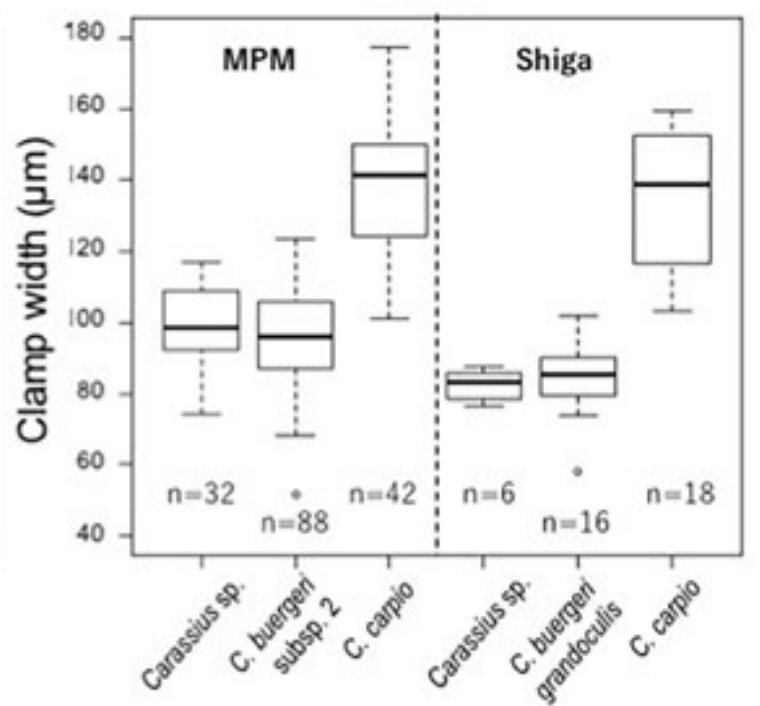

Fig. 6. Box-plot of clamp width of Eudiplozoon spp. from different host species/locality. The bold line indicate the median; box indicates upper and lower quartiles; line indicates the maximum and minimum values within 1.5 times of the upper and lower quatiles. Left three box-plots indicating the measurements of Eudiplozoon specimens in Meguro Parasitological Museum (MPM) and right three box-plots indicating those of Eudiplozoon specimens obtained from Shiga Prefecture in the present study.

structure rather than a sclerite, at posterior end of median sclerite connecting with posterior clamp jaws.

No morphological differences were detected in the anterior joining sclerites of diplozoids from different host genera.

Figure 6 shows the clamp width of diplozoids from Carassius sp., C. buergeri grandoculis and C. carpio (Eurasian type), with the measurements of the specimens in MPM. In the Lake Biwa water system, clamp width ranges of diplozoids from different host genera (Carassius or Cyprinus) did not overlap for all four clamps. Among MPM specimens, clamp width overlapped between diplozoids from different host genera but, most individuals could be distinguished from worms obtained from the other host genera by the width of clamps II and III. Clamp II widths were $<120 \mu \mathrm{m}$ in $97 \%$ of diplozoids from Carassius (Carassius sp. and C. buergeri subsp. 2), and $\geq 120 \mu \mathrm{m}$ in $95 \%$ of those from C. carpio. Clamp III widths were $<120 \mu \mathrm{m}$ in $94 \%$ of diplozoids from Carassius, and $\geq 120 \mu \mathrm{m}$ in $95 \%$ of those from C. carpio (Fig. 6). Clamp width is correlated to the host standard length in diplozoids from $C$. buergeri grandoculis, but is not in diplozoids from C. carpio (Fig. 7; an example of clamp III). Clamp width little overlapped between diplozoids from Carassius and those from C. carpio even if their host sizes are almost same.

\section{Morphological descriptions of Eudiplozoon nipponicum and Eudiplozoon kamegaii sp. $\mathbf{n}$.}

Based on these molecular and morphological results, we concluded that speciemens of Eudiplozoon from species of Carassius spp. and from Cyprinus carpio (Eurasian type) are separate species. We therefore redescribe E. nipponicum and designate its neotype, and describe a new species from C. carpio. 


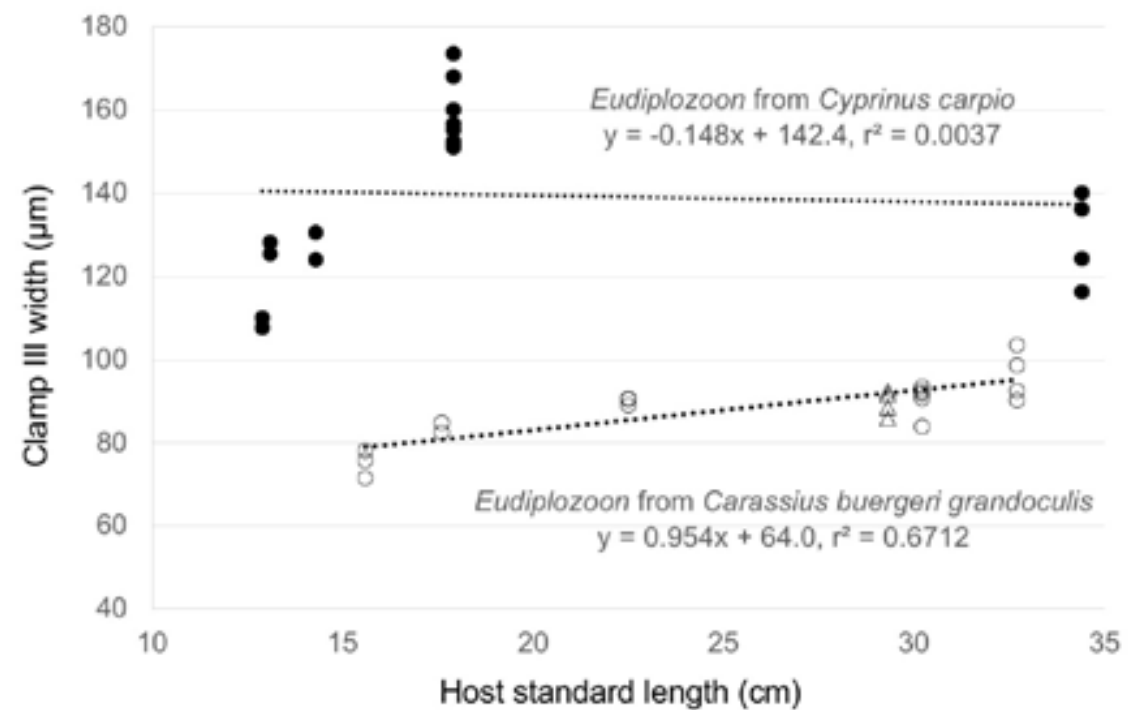

Fig. 7. Relationship between host standard length and clamp III width. Based on seven pairs of Eudiplozoon from 5 Cyprinus carpio (closed circle), six pairs from five Carassius buergeri grandoculis (open circle) and two pairs from Carassis sp. (open triangle). Linear regression lines are shown for Eudiplozoon from C. carpio and from C. buergeri grandoculis.

\section{Class Monogenea van Beneden, 1858}

\section{Family Diplozoidae Palombi, 1949}

\section{Genus Eudiplozoon Khotenovsky, 1985}

\section{Eudiplozoon nipponicum (Goto, 1891) Khotenovsky, 1985}

Fig. 4

Syns. and records: Diplozoon nipponicum Goto, 1891: Goto (1891), pp. 151-190, plts XXI-XXIII; Yin and Sproston (1948), pp. 82-85, table VI; Reichenbach-Klinke (1961), pp. 541-557, fig. 5e (after Goto 1891), Bychowsky (1962), p. 381 (in part), fig. 844 (species uncertain); Yamaguti (1963), p. 233 (only citation of Goto 1891); Kamegai (1968), pp. 1-8 (in part), figs. 2-5 (oncomiracidia, species uncertain); Osmanov (1971), p. 138 (in part); Kamegai (1976), pp. 1-9 (host record only); Kawatsu (1978), pp. 1315-1319 (host record only); Kimura (1977), pp. 5-14 (in part), figs. 3-5 (species uncertain); Kitahara et al. (1986), pp. 1307-1312 (host record only); Mizuo et al. (1999), pp. 46-50 (host record only); Anonymous (2002), pp. 206-218 (host record only);

Diplozoon sp.: Strelkov (1971), p. 71, No. 134 (host record only);

Sindiplozoon nipponicum (Goto, 1891) Khotenovsky, 1981 (in part): Khotenovsky (1981), pp. 166-178 (in part);

Eudiplozoon nipponicum (Goto, 1891) Khotenovsky, 1985 (in part): Khotenovsky (1985), pp. 214-218 (figs. 152-156 show E. kamegaii); Bauer et al. (1985), pp. 379-380 (in part), figs. 603, 604 (after Khotenovsky 1985, showing E. kamegaii); Jiang et al. (1989), pp. 259-269 (in part); Nagasawa et al. (1989), p. 9 (in part) (host record only); Jiang (1991), pp. 193-194 (in part) (fig. 197 and plts 1, 2 perhaps show E. kamegaii); Ogawa (1994), p. 62 (in part) (host record only); Lü et al. (1996), p. 49 (in part) (host record only); Jiang (2000), pp. 672-674 (in part) (fig. 597A after Jiang 1991, 597B after Chen 1973, both showing E. kamegaii), plate II-8, 9 (species uncertain); Molodozh- nikova and Zhokhov (2006), p. 346 (in part) (host record only); Pugachev et al. (2010), pp. 508-509 (in part), figs. 703-704 (after Khotenovsky 1985, showing E. kamegaii); Ogawa (2011), pp. 1463, 1464 (in part) (host record only); Eudiplozoon sp.: Sicard et al. (2003), pp. 199-211; Zhang et al. (2018), additional file 8a-d.

Although there are a lot of abstracts on Diplozoon nipponicum by Satoru Kamegai, most of them record only host species and include no taxonomical information (see Nagasawa 2016 for these abstracts). There are also many books referring to D. nipponicum or E. nipponicum without any original data, but we do not list most of these references in this paper.

Neotype (one pair): NSMT-P1 6408 (neotype), National Museum of Nature and Science, Tokyo (Fig. 4A-D)

Host of ne oty pe: Carassius buergeri grandoculis (Cyprinidae) (Japanese name nigorobuna).

Site of infection: Gills.

Collection site of ne otype: A canal near Lake Biwa in Harie, Shin-asahi Town, Takashima City, Shiga Prefecture, Japan.

Collection date: 27 June 2016.

Reference specimens: (1) NSMT-Pl 6409 (host: C. buergeri grandoculis collected at Harie on 13 July 2017), NSMT-P1 6410 (host: C. buergeri grandoculis collected at Ohta on 9 June 2019), NSMT-P1 6411 (host: Carassius sp. collected at Ohta on 9 June 2019), Institute of Parasitology M-725 (host: C. buergeri grandoculis collected at Ohta on June 19, 2018), three adult pairs found on Carassius sp. collected from the Ohta biotope collected on 4 and 19 June 2018 and 9 June 2019 in M. Urabe's personal collection, and 24 pairs found on C. buergeri grandoculis from the Harie and Ohta biotope in May-August 2016, May-July 2017, MayJune 2018, and 9 June 2019, at M. Urabe's personal collection. (2) 39 pairs of adults collected from Carrasius sp. (ginbuna), 69 from C. buergeri subsp. 2 and 1 from Carassius sp. (species unknown) deposited in the Meguro Parasitological Museum during 1965 to1980 (see Supplementary Table 2). 
Description of neotype. Measurement of paired worms ( 2 individuals) in micrometres $(\mu \mathrm{m})$ unless otherwise stated. A pair of individuals fusing together to form $\mathrm{X}$-shaped body (Fig. 4A). Body constructed of two parts: forebody filled with vitelline follicles and hindbody with haptors including four pairs of clamps and one pair of central hooks for host attachment. In holotype, one haptor missing two clamps and both haptors missing one hook. Body $4.94-5.20 \mathrm{~mm}$ long. Forebody $2.85-3.19 \mathrm{~mm}$ long. Hindbody $0.97-1.06 \mathrm{~mm}$ long, with $15-16$ folds, terminated as blunt haptor. Posterior third of hindbody except haptor dilated, with 5-6 wide folds (Fig. 4C). Anterior end of median sclerite of clamps having small projection connected to arcuate sclerite. Arcuate sclerite connecting median sclerite with clamp jaws. Anterior and posterior clamp jaws having cross striation on their inner side (Fig. 4E). Clamp I (posterior), 32 long $(\mathrm{n}=1)$ and $67-77$ wide $(\mathrm{n}=2)$; clamp II, 38 long $(\mathrm{n}=1)$ and 76 wide $(\mathrm{n}=2)$; clamp III, 40-44 long $(\mathrm{n}=$ 2) and 76-81 wide $(\mathrm{n}=2)$; clamp IV (anterior), 44-69 long $(\mathrm{n}=2)$ and $77-81$ wide $(\mathrm{n}=2)$. Central hooks medial to clamps IV, having handle 50 long $(\mathrm{n}=2)$ and shaft 21-22 long $(n=2)$ (Fig. 4F).

Mouth opens anterovental, almost closing, leading to large buccal cavity (Fig. 4B). Buccal suckers 106-127 long and 76-93 wide $(\mathrm{n}=4)$. Musculo-glandular organs ("sticky gland" of Goto 1891) anterior to buccal sucker, 37-52 long and 31-40 wide $(n=4)$. Pharynx elliptic, $68-77$ long and 31-40 wide. Transverse nerve commissure dorsal to oesophagus. Lateral diverticula of intestine in forebody unclear. Intestine in hindbody tubulate, ending blindly (Fig. 4C). Intestine loop in hindbody described by Goto (1891) unclear.

Testis one, with several shallow-notched lobules, posteromedial to ovary, in base of hindbody, 432-508 long and 159 wide $(\mathrm{n}=2)$ (Fig. 4D). Ovary pretesticular, kidney-shape with one elongated projection, 635-752 long and $317-336$ wide $(n=2)$. Oviduct arising from nearly distal end of ovary, receiving genitointestinal canal and common vitelline duct forming short ovovitelline duct, posterior to ovary. Distal part of genitointestinal canal not clearly observed. Ovovitelline duct leading to ootype. Ootype large, ellipitic, sinistral to ovary.

Uterus running along anterior edge of ovary of another individual. Uterus opening at body fusion part, without any visible structure. Eggs spindle-shaped, with single long filament on opposite side of uterus opening. Egg in uterus 290 long (not including filament) and 89 wide. Egg filament in uterus coiling, unmeasured.

\section{Measurements and supplemental description of reference specimens}

Based on 32 specimens obtained in the present study, including neotype. Body 3.11-10.24 mm long $(\mathrm{n}=25)$. Forebody $1.34-6.34 \mathrm{~mm}$ long $(\mathrm{n}=26)$. Hindbody 0.79 $3.12 \mathrm{~mm}$ long $(\mathrm{n}=26)$. Third section of quarters of hindbody broader, with 3-4 thick folds. Based on 32 specimens obtained in the present study, including neotype. Body $3.11-10.24 \mathrm{~mm}$ long $(\mathrm{n}=25)$. Forebody $1.34-6.34 \mathrm{~mm}$ long $(\mathrm{n}=26)$. Hindbody $0.79-3.12 \mathrm{~mm}$ long $(\mathrm{n}=26)$.
Third section of quarters of hindbody broader, with 3-4 thick folds. Clamp I, 43-90 wide $(\mathrm{n}=22)$; clamp II 74-101 wide $(\mathrm{n}=21)$; clamp III $72-103$ wide $(\mathrm{n}=21)$; clamp IV, 58-102 wide $(\mathrm{n}=22)$. Central hook 40-56 long $(\mathrm{n}=22)$, sometimes with wing (Fig. 4F). Musculo-glandular organs 27-52 long and 44-49 wide $(\mathrm{n}=18)$. Buccal sucker 72 150 long and 63-147 wide $(\mathrm{n}=36)$. Pharynx 20-77 $\mu \mathrm{m}$ long and $19-53$ wide $(n=11)$. Intestine in forebody having lateral diverticula. Intestine loop in hindbody described by Goto (1891) unclear. Egg in uterus 250-438 long (not including filament) and $81-219$ wide $(\mathrm{n}=7)$. Hindbody with 14-18 folds (median 16; $\mathrm{n}=10$ ).

Remarks. These diplozoids are identified as E. nipponicum, according to the original description of this species by Goto (1891). Goto (1891) described the type host of D. nipponicum as Carassius vulgaris, which is probably Carassius sp. (ginbuna) or C. buergeri subsp. 2 (kinbuna) (Shimazu et al. 2015, Nagasawa 2016). Therefore, we agree with Shimazu et al. (2015) that the scientific name E. nipponicum should be applied to the species from Carassius spp., not to the species from Cyprinus carpio. The present study reveals $C$. buergeri grandoculis is another host of E. nipponicum.

There is no record of the type locality in the original description by Goto (1891). Fujita (1937) remarked the type locality as "Senju, Tokyo", which is now Adachi Ward, Tokyo. Kamegai et al. (1966) and Kamegai (1968) remarked the type locality as "a pond in the Shimura district, a suburb of Tokyo", which probably refers to Shimura, Itabashi Ward, Tokyo (Shimazu et al. 2015, Nagasawa 2016). Therefore, it is likely that Goto (1891) collected type host from a pond in northern Tokyo, although the exact location remains unknown. We attempted to collect Carassius fish from some localities near Tokyo, but we could obtain only 10 fish, which harboured no diplozoids, from one locality (Ichinomiya). Goto (1891) also reported that D. nipponicum was found in various places in Japan.

Ge ographical distribution: Japan (Hokkaido, Honshu), China, Russia (Amur and Volga regions)

Hosts described in the literature: Carassius vulgaris (now ginbuna, Carassius sp. or kinbuna C. buergeri subsp. 2 - Goto 1891, Shimazu et al. 2015, Nagasawa 2016): goldfish Carassius carassius (misidentification of C. auratus?) (Yin and Sproston, 1948), C. cuvieri (?) (no morphological description) (Kamegai 1977): Carassius auratus (ginbuna, now Carassius sp.) (Sicard et al. 2003, Shimazu et al. 2015)

\section{Eudiplozoon kamegaii sp. $\mathbf{n}$.}

Fig. 5

ZooBank number for species: urn:Isid:zoobank.org:act: 35BC1E5F-A9EA-4382-9B84-124FD997F98A

Syns. and records: Diplozoon nipponicum Goto, 1891: Bychowsky (1962), p. 391 (in part), fig. 844 (species uncertain); Kamegai et al. (1965), pp. 607, 608; Kamegai et al. (1966), pp. 2-9, figs. 1-6; Kamegai (1968), pp. 1-8 (in part), figs. 2-5 (oncomiracidia, species uncertain); Koval and Pashkevishute (1969), pp. 232, 233 (host record 
only); Kamegai (1970a), pp. 21-25, figs. 1, 2, 4; Kamegai (1970b), p. 20, fig. (not numbered); Osmanov (1971), p. 138 (in part); Kamegai (1973), p. 98; Chen (1973), p. 154, plate XCIV, figs. 234-238; Kamegai (1976), pp. 1-9 (host record only); Kimura (1977), pp. 5-14 (in part), figs. 3-5 (species uncertain); Lambert and Denis (1982), pp. 533-542, figs. 1-3 (oncomiracidia); Denis et al. (1983), pp. 128-134 (host record only); Le Brun et al. (1985), pp. 105-109, photos 1A,B; Rhee (1985), pp. 331-333, figs. 1-4; Kamegai (1986), p. 35 (host record only); Hirose et al. (1987), Figs. 1 and 4 (oncomiracidium); Izyumova (1987), p. 137, 206 (host record only); Le Brun et al. (1988), pp. 395-400; Samman (1989), pp. 45-50 (host record only); Jovelin and Justine (2001), pp. 393-401; Al-Nasiri (2003), pp. 95-99, fig. 1;

Diplozoon sp.: Strelkov (1971), p. 71, No. 135 (host record only);

Sindiplozoon nipponicum (Goto, 1891) Khotenovsky, 1981 (in part): Khotenovsky (1981), pp. 166-178;

Eudiplozoon nipponicum (Goto, 1891) Khotenovsky, 1985 (in part): Kornakova (1983), pp.102-105, figs. 7-10 (nomen nudum, without a description or definition that are purported to differentiate the taxon ICZN: 13.1.1); Khotenovsky (1985), pp. 214-218, figs. 152-156; Bauer et al. (1985), pp. 379-380 (in part), figs. 603, 604 (after Khotenovsky 1985); Jiang et al. (1989), pp. 259-269 (in part); Nagasawa et al. (1989), p. 9 (in part) (host record only); Svobodová et al. (1990), pp. 3-13 (host record only); Jiang (1991), pp. 193, 194 (in part) (fig. 197 and plts 1,2 perhaps show E. kamegaii); Nedeva (1991), pp. 35-37, fig. 6; Pojmańska and Chabros (1993), pp. 101-108 (host record only); Lü et al. (1996), p. 49 (in part) (host record only); Ogawa (1994), p. 62 (in part) (host record only); Jažić (1997), pp. 82, 83, fig. 1 (after Khotenovsky 1985): Székely and Molnár (1998), pp. 45-54 (host record only); Jiang (2000), pp. 672-674 (in part), fig. 597A (after Jiang 1991), 597B (after Chen 1973), plate II-8, 9; Littlewood and Olson (2001), pp. 262-278 (18S sequence, accession no. AJ287510); Matejusová et al. (2001), pp. 465-474, fig. 1; Sicard et al. (2001), pp. 709-717; Zurawski et al. (2001), pp. 783-792, figs. 1-4; Olson and Littlewood (2002), pp. 233-244; Sicard et al. (2002), pp. 85-87; Cojocaru (2003), pp. 73-74 (host record only); Sicard et al. (2003), pp. 199211; Zurawski et al. (2003a), pp. 198-200, figs 1,2; Zurawski et al. (2003b), pp. 349-357, figs. 1-4 (diporpae); Matejusová et al. (2004), pp. 817-822, figs. 2H; Oganessyan (2004), pp. 88-93 (host record only); Schabussova et al. (2004), pp. 63-68, fig. 1; Gao et al. (2007), pp. 695-703; Molodozhnikova and Zhokhov (2006), p. 346 (in part) (host record only); Stojanovski et al. (2008), pp. 389-398, figs. 14-15; Oganessyan (2009), pp. 32-37, fig. 1 (copy from Khotenovsky 1985, showing E. kamegaii); Pugachev et al. (2010), pp. 508-509 (in part), figs. 703, 704 (copy from Khotenovsky 1985, showing E. kamegaii); Hodová and Matejusová (2010), pp. 702-709, figs. 1-5; Košková et al. (2010), pp. 909-914, fig. 1; Hodová et al. (2011), pp. 2-4, figs. 1-5 (after Hodová and Matejusová 2010 and Valigurová et al. 2011); Ogawa (2011), pp. 1463-1464 (in part) (host record only); Valigurová et al. (2011), pp. 383-
394, figs. 1-6; Rohlenová et al. (2011), p. 120 (host record only); Ondračková et al. (2012), pp. 1487-1493 (host record only); Zhang et al. (2012), pp. 576-580 (host record only); Šimková et al. (2013), Tavakol et al. (2013), p. 92 (host record only); Mhaisen and Abdul-Ameer (2014), p. 98, fig. (2)-2 (after Khotenovsky 1985); Mhaisen et al. (2015), p. 54 (host record only); Konstanzová et al. (2016), pp.1493-1500, figs. 2A, B, 3a-d; Šmiga et al. (2016), pp. 169-172 (host record only); Jedličková et al. (2016), pp. 494-506; Mhaisen and Al-Rubae (2016), p. 8 (host record only); Ilgová et al. (2017), pp. 1-12 (host record only); Konstanzová (2017) p. 30 (host record only); Jedličková et al. (2018), pp. 1-17; Mhaisen et al. (2018), pp. 195-196 (host record only); Roudnický et al. (2018), pp. 1-13; Caña-Bozada et al. (2019), pp. 1-11; Fedorovych and Gutyj (2019), pp. 146-151 (host record only); Ilgová et al. (2019), pp. 1-4 (host record only); Jedličková et al. (2019), pp. 337-346, fig. 8; Mhaisen (2019), p. 159 (host record only); Chmúrčiaková et al. (2020), pp. 1-8 (host record only).

Ty pe host: Cyprinus carpio Linnaeus (Cyprinidae) (Eurasian type; Japanese name koi)

Site of Infection: Gills.

Type locality: Shinhama (near Lake Biwa), Kusatsu City, Shiga Prefecture, Japan.

D a te : 10 November 2017.

Holotype (one pair): NSMT-Pl 6405, National Museum of Nature and Science, Tokyo

Paratypes (three pairs): NSMT-pl 6406 (collected at Hachiyado on Feburuary 25, 2017), NSMT-pl 6407 (collected at Shinhama on September 25, 2018), Institute of Parasitology M-726 (collected at Shinhama on November 10, 2017)

Reference specimens: Six pairs of adults collected at Shinhama and Hachiyado during 2017-2018 in M. Urabe's personal collection; 76 pairs of adults in the Meguro Parasitological Museum (see Supplementary Table 2).

Description of holotype. A pair of individuals fusing together to form an X-shaped body (Fig. 5). Body consisting of forebody filled with vitelline follicles and hindbody with haptors including four pairs of clamps and one pair of central hooks, but only one hook remaining in holotype. Body 6.86-7.51 mm long. Forebody 3.59-3.97 mm long. Hindbody $2.23-2.47 \mathrm{~mm}$ long, having $23-25$ folds. Third section of quarters of hindbody dilating, with 4-5 thick folds. Hapter occupying posterior quarters of hindbody, having 4 pairs of clamps (Fig. 5C). Haptor missing 3 of 4 central hooks. Anterior end of median sclerite of clamps having small projection connected to arcuate sclerite (Fig. 5E). Arcuate sclerite connecting median sclerite with clamp jaws. Weak cross striation present both on posterior clamp jaw, lateral sclerite of posterior jaw, and upper part of anterior clamp jaw. Clamp I, 69-79 long and 120-130 wide $(\mathrm{n}=4)$; clamp II, 83-100 long and 148-161 wide $(\mathrm{n}=4)$; clamp III, 86-96 long and 149-171 wide $(\mathrm{n}=4)$; clamp IV, 90101 long $(n=3)$ and $146-159$ wide $(n=4)$. Central hook submedian, medial to clamp II, having handle 38 long and shaft 22 long $(n=1)$. 
Mouth anterovental, leading to large buccal cavity (Fig. 5B). Buccal sucker paired, elliptic, 161-180 long and 128-146 wide $(\mathrm{n}=4)$. Musculo-glandular organs anterior to oral sucker, subterminal, paired, globular, smaller than buccal sucker and pharynx, 57.9-68.9 long and 49-58 wide $(\mathrm{n}=4)$. Pharynx elliptic, 88-89 long and 56-67 wide $(\mathrm{n}=2)$. Transverse nerve commissure dorsal to oesophagus. Lateral diverticula of intestine in forebody unclear. Intestine in hindbody with weak lateral diverticula, ending blindly anterior to clamps (Fig. 5C).

Testis one, with several shallow-notched lobules, in second section of quarters of hindbody, 444 long and 254-368 wide $(n=2)$ (Fig. 5D). Ovary pretesticular, anterior margin obvious, 527-603 long and 317 wide $(n=2)$. Oviduct arising from distal or proximal end of ovary, receiving genitointestinal canal. Distal part of genitointestinal canal not clearly observed. Oviduct receiving common vitelline duct near ootype, forming short ovovitelline duct. Ootype large, ellipitic, sinistral to ovary. Uterus running forward gonads of another individual. Uterus opening at body fusion part, without any visible structure. No eggs observed in uterus.

\section{Measurements and supplemental description of paratypes and reference specimens}

Based on 10 pairs (including holotype) obtained in this study. Body 3.79-7.53 mm long $(\mathrm{n}=20)$. Forebody 2.13 $3.97 \mathrm{~mm}$ long $(\mathrm{n}=20)$. Hindbody $1.12-2.50 \mathrm{~mm}$ long (n $=20$ ), with $16-25$ folds (median $21 ; n=17$ ). Clamp I distal, 89-128 wide $(\mathrm{n}=18)$; clamp II $103-170$ wide $(\mathrm{n}=$ 19); clamp III 108-174 wide $(\mathrm{n}=18)$; clamp IV proximal, 103-160 wide $(\mathrm{n}=18)$. Central hook 38-53 long $(\mathrm{n}=24)$. Musculo-glandular organs 24-69 long and 27-61 wide (n $=22$ ). Buccal sucker 87-180 long and 74-146 wide ( $\mathrm{n}=$ 34). Pharynx globular or oval, 62-106 long and 42-87. wide $(\mathrm{n}=18)$. Intestine in hindbody tubulate with small projections. Ovary and testis in hindbody, sometimes with ambiguous outline. No eggs found in our specimens.

Ety m ology: This new species is named in honour of Satoru Kemagai (1909-2002), founder of the Meguro Parasitological Museum, Tokyo, Japan.

Ge ographical distribution: China, Japan (Hokkaido, Honshu), Russia (native Amur region?), South Korea.

Introduced countries: Armenia, Belarus, Bosnia-Herzegovina, Bulgaria (?), Czech Republic, France, Hungary, Iran (?), Iraq (?), Kazakhstan, Macedonia (?), Moldova, Poland, Romania (?), Slovakia (?), Ukraine.

Hosts described in the literature: Cyprinus carpio sensu lato (Kamegai 1973, Le Brun et al. 1985, Matejusová et al. 2001, 2004, Sicard et al. 2001, 2002, Gao et al. 2007, Hodová and Matejusová 2010, Pugachev et al. 2010 - in part, Wan and Yue 2015).

Remarks. Clamp width in this species was generally larger than that of Eudiplozoon nipponicum sensu stricto in all clamps (Fig. 6). The hindbody often has more than 19 folds in this species, whereas the hindbody of E. nipponicum never exceeds 19 folds. Although their ranges partly overlap, generally, these two species can be morphologically distinguished by these characteristics.
Genetic variation in the ITS-2 region of this species is small in relation to its wide geographic distribution (Table 2). Among the 14 individuals analysed in this study, 8 had identical sequences to those of E. nipponicum from C. carpio obtained in the Czech Republic (AJ300710) and China (DQ098897). The distribution and phylogeny of wild carp remain controversial because they have been transplanted by humans for many years (Kohlmann and Kersten 2013, Dong et al. 2015, Xu et al. 2019). It is very plausible to assume that E. kamegaii has also spread rapidly with its hosts, as suggested by Khotenovsky (1981). In Europe, E. kamegaii (reported as E. nipponicum) is considered to be an introduced species (Lambert and Denis 1982, Jedličková et al. 2018).

There are many records of E. nipponicum in C. carpio from Japan and many Eurasian countries. These can be identified as E. kamegaii when their descriptions include DNA information, clamp measurements, or number of folds on hindbody (Kamegai et al. 1965, 1966, Osmanov 1971, Chen 1973, Kamegai 1973, Le Brun et al. 1985, Rhee 1985, Nedeva 1991, Jovelin and Justine 2001, Matejusová et al. 2001, 2004, Sicard et al. 2001, 2002, 2003, Olson and Littlewood 2002, Gao et al. 2007, Hodová and Matejusová 2010, Pugachev et al. 2010, Valigurová et al. 2011, Wan and Yue 2015). There are many papers that reported E. nipponicum from $C$. carpio but provided neither sufficient morphological description nor genetic analysis (e.g., Kamegai 1968, 1970a,b, Lambert and Denis 1982, Denis et al. 1983, Hirose et al. 1986, Lambert and Le Brun 1988, Le Brun et al. 1988, Zurawski et al. 2001, 2003a,b, Al-Nasiri 2003, Stojanovski et al. 2008, Konstanzová et al. 2016, Jedličková et al. 2016). It is probably that these papers also reported E. kamegaii, but further confirmation is needed.

\section{DISCUSSION}

Specimens of Eudiplozoon from species of Carassius and Cyprinus carpio collected from the same water system were classified into different clusters in the phylogenetic tree based on the ITS-2 region (Figs. 2 and 3). The substitution rates of bases between different host genera were $3.1-4.0 \%$ among ITS-2 sequences, significantly higher than those within the clusters, and comparable to those between monogenean species (6.9-24.5\%) reported in a previous study (Matejusová et al. 2001).

There was large variation among COI haplotypes in Eudiplozoon spp.; neither individuals from the same host genus nor those from the same locality formed a single clade. Incongruence is frequently observed between phylogenetic trees calculated based on mitochondrial or nuclear DNA in invertebrates, including monogeneans, for several reasons including hybridisation (e.g., Ziętara et al. 2010, Lumme et al. 2017). Further data are clearly needed for COI phylogenetic tree of Eudiplozoon spp.

There are no significant differences in clamp sclerite morphology, which is a key characteristic often used to distinguish diplozoid species (Matejusová et al. 2001, Pugachev et al. 2010). We could not describe the exact morphology of intestine branching, which is also a key characteristic in diplozoids (Pugachev et al. 2010). It was 
hard to observe this characteristic in our specimens, so further study is needed using some newly collected, living samples. However, they were generally distinguishable using clamp width or the number of folds on the hindbody (Fig. 6). Clamp width correlated with host standard length in specimens of Eudiplozoon from Carassius buergeri grandoculis. In specimens from $C$. carpio, clamp width did not correlate with host standard length, but the plots in Fig. 7 suggest that it has a positive correlation with host standard length in the cases of small hosts. Anyway, when one compares individuals from Carassius and those from C. carpio with almost same size, their clamp width was clearly different from each other, as shown in Fig. 7. These morphological differences support the view that these specimens from different host genera belong to different species. We therefore concluded that Eudiplozoon from species of Carassius and those from $C$. carpio belong to different species.

Eudiplozoon nipponicum from species of Carassius has been recorded only from Japan (Goto 1891, Kamegai 1968, 1974a,b, 1975a,b, 1976, 1977, Kawatsu 1978, Ichihara et al. 1980, Nagasawa et al. 1989, Mizuo et al. 1999, Anonymous 2002, Sicard et al. 2003), China (Yin and Sproston 1948, Jiang 1991, Zhang et al. 2018), and Russia (Amur River) (Bychowsky 1962, Strelkov 1971), not considering a questionable record from Uzbekistan, which lists only common host names in Russian (Osmanov 1971). All records of E. nipponicum from Europe are from C. carpio.

Therefore, it is likely that E. nipponicum sensu stricto is distributed only in East Asia, although it should be taxonomically reinvestigated, especially based on nuclear DNA sequence. There are also many studies on E. nipponicum from Japan and Eurasian countries, which regarded diplozoids from $C$. carpio and species of Carassius spp. as a single species, often without supporting morphological or host information (e.g., Kamegai 1968, 1976, Kimura 1977, Nagasawa et al. 1989, Ogawa 1994, Šimková et al. 2013, Nagasawa 2016, Jedličková et al. 2018). Further taxonomical study is needed to clarify these specimens.

There are some records of Eudiplozoon spp. from fishes which are not investigated in this study as mentioned in the Introduction (Carassius auratus gibelio, Cyprinus carpio rubrofuscus, Abramis brama, Capoeta capoeta heratensis, Luciobarbus capito conocephalus, Leuciscus vorax, Mesopotamichthys sharpeyi, Channa argus). None of them are described morphologically nor studied for genetic information, and we cannot estimate whether they are E. nipponicum, Eudiplozoon kamegaii, or unknown species.

Acknowledgements. We are grateful to Satosu Kirano, Nagano Environmental Conservation Research Institute, Yasuo Araki, Yamagata Prefectural Inland Fishery Institute, Akiko Minagawa and Kiyohito Morii, University of Shiga Prefecture, for their help to sample fishes. We also thank Shin-Asahi Land Improvement Association and Japan Water Agency for the permission of fish sampling in Takashima City. Meguro Parasitological Museum allowed us to study specimens prepared by S. Kamegai, and helped to get literatures on diplozoids. Takeshi Shimazu, Azumino City, Nagano Prefecture, advised us to study diplozoids and made many useful comments on early drafts. Natalia I. Yurlova, Institute of Systematic and Ecology of Animals SB RAS, Novosibirsk, Nadezhda B. Terenina, Institute of ecology and evolution RAS, Konstantin S. Vainutis, Federal Scientific Center of the East Asia Terrestrial Biodiversity, Masahito Nitta, Kobe University, helped us with search of literature concerned. Takafumi Nakano, Kyoto University gave us advice on the interpretation of the International Code of Zoological Nomenclature. We thank all members of the Laboratory of Hydrosphere for their daily useful advice and discussion for our study, and students of the University of Shiga Prefecture for their help in our field sampling.

\section{REFERENCES}

Al-Nasiri F.S. 2003: First occurrence of the monogenetic trematode Diplozoon nipponicum Goto, 1891 in Iraq from common carp Cyprinus carpio (Pisces). Iraqi J. Agric. 8: 95-99.

Al-SaAdi A.A.J., Mhaisen F.T., Hasan H.R. 2010: Ectoparasites of seven fish species from Al-Husainia Creek, Karbala province, Mid Iraq. J. Kerbala Univ. 8: 1-7.

ANONYMOUS 2002: [Fish parasite fauna and its feature in the experimental rivers of Aqua Restoration Research Center.] Ann. Rep. Aqua Restoration Res. Center 2001, pp. 206-218. (In Japanese.)

Bauer O.N., Gusev A.V., Scarlato O.A. (Eds) 1985: [Key to Parasites of Freshwater Fish of the U.S.S.R.] Vol. 2. Nauka, Leningrad, Russia. 426 p. (In Russian.)

Bowles J., Blair D., McManus D.P. 1995: A molecular phylogeny of the human schistosomes. Mol. Phyl. Evol. 4: 103-109.

Bychowsky B. B. 1962: [Genus Diplozoon Nordmann, 1832.] In: B. B. Bychowsky, Review of Key to Parasites of Freshwater Fish of the U.S.S.R. Izdatel'stvo Akademii Nauk SSSR., Moscow-Leningrad, pp. 379-383. (In Russian)

Caña-Bozada V., Morales-Serna F.N., García-Gasca A., Llera-Herrera R., Fajer-Ávila E.J. 2019: Genome-wide identification of ABC transporters in monogeneans. Mol. Biochem. Parasitol. 234: 1112342

Chen C.L. (ED.) 1973: [An Illustrated Guide to Fish Diseases and Causative Pathogenic Fauna and Flora in the Hubei Province.] Academia Sinica Press, Beijing, 456 pp. (In Chinese.)
Chmúrčiaková N., KašnÝ M., Orosová M. 2020: Cytogenetics of Eudiplozoon nipponicum (Monogenea, Diplozoidae): karyotype, spermatocyte division and 18S rDNA location. Parasitol. Int. 76: 102031

COJOCARU C.D. 2003: The infestation of carp (Cyprinus carpio) with monogenean of family Diplozooidae. Romanian J. Parasitol. 8: 73-74

Denis A., Gabrion C., Lambert A. 1983: Présence en France de deux parasites d'origine est-asiatique: Diplozoon nipponicum Goto, 1891 (Monogenea). Bull. Fr. Piscic. 289: 128-134.

Dong C., Xu J., Wang B., Feng J., Jeney J., Sun X., Xu, P. 2015: Phylogeny and evolution of multiple common carp (Cyprinus carpio L.) populations clarified by phylogenetic analysis based on complete mitochondrial genomes. Mar. Biotech. 17: $565-575$.

Fedorovych O.V., Gutyu B.V. 2019: [State of the organism of the same year scaly carp infected by Eudiplozoon nipponicum.] Vet. Sci. 21: 146-151. (In Ukrainan with English abstract.)

Fujita T. 1937: [Fish Diseases]. Kouseikaku, Tokyo, 304 pp. (In Japanese.)

FujiwARA K., Usuki T. 1994: [Fry discrimination of the three species of Carassius]. In: Annual reports of Shiga Prefectural Fisheries Experiment Station, pp. 28-29. (In Japanese.)

Gao Q., Chen M.X., Yao W.J., Gao Y., Song Y., Wang G.T. 2007: Phylogeny of diplozoids in five genera of the subfamily 
Diplozoinae Palombi, 1949 as inferred from ITS-2 rDNA sequences. Parasitology 134: 695-703.

Goto S. 1891: On Diplozoon nipponicum n. sp. J. Coll. Sci. Imp. Univ. Jap. 4: 21-23 + 21-23 Plts.

Hirose H., Akamatsu H., Hibiya T. 1987: [On the development of clamps and pairing of diporpae in Diplozoon nipponicum (Monogenea).] Nippon Suisan Gakkaishi 53: 953-957. (In Japanese with English abstract.)

Hodová I., MatĚJusová I. 2010: The surface topology of Eudiplozoon nipponicum (Monogenea) depelopmental stages parasitizing carp (Cyprinus carpio L.). Centr. Eur. J. Biol. 5: 702-709.

Hodová I., VAligurová A.B., Sonnek R. 2011: Body architecture of the parasitic worm visualization of muscular structures by LM, SEM and CLSM. Imaging Micros. 13: 2-4.

Ichihara A., Kamegai S., Kanmegai S. 1980: [Study of the genus Diplozoon No. 24 Seasonal change of prevalence and prevalence difference between sexes in Carassius spp. near Maruko Bridge, Tama River.] Jpn. J. Parasitol. 19: 17. (In Japanese.)

Ilgová J., Jedličková L., Dvořáková H., Benovic M., Mikeš L., Janda L., Vorel J., RoudnickÝ P., РotěšIl D., Zdráhal Z., Gelnar M., KaŠnÝ M. 2017: A novel type I cystatin of parasite origin with atypical legumain-binding domain. Sci. Rep. 7: 17526.

Ilgová J., Kavanová L., MatiašKová K., Salat J., KašnÝ M. 2019: Effect of cysteine peptidase inhibitor of Eudiplozoon nipponicum (Monogenea) on cytokine expression of macrophages in vitro. Mol. Biochem. Parasitol. 235: 111248.

Izyumova N.A. 1987: Parasitic Fauna of Reservoir Fishes of the USSR and its Evolution. Oxonian Press, New Delhi and Calcutta, $325 \mathrm{pp}$.

JAŽIĆ A. 1997: [Parasitofauna in carp and its importance to fisheries in Bosnia-Herzegovina.] Veterinaria (Sarajevo) 46: 71-88. (In Croatian with English abstract.)

Jedličková L., Dvořáková H., Dvořák J., KašNÝ M., UlRYChOvÁ L., Vorel J., ŽÁrskÝ V., Mikeš L. 2018: Cysteine peptidases of Eudiplozoon nipponicum: a broad repertoire of structurally assorted cathepsins L in contrast to the scarcity of cathepsins B in an invasive species of haematophagous monogenean of common carp. Parasit. Vectors. 11: 142.

JedličKová L., Dvořák J., Hrachovinová I., Ulrychová L., KAŠNÝ M., MiKeš L. 2019: A novel Kunitz protein with proposed dual function from Eudiplozoon nipponicum (Monogenea) impairs haemostasis and action of complement in vitro. Int. J. Parasitol. 49: 337-346.

JedličKová L., DvoŘÁKová H., KašNÝ M., Ilgová J., PotěšIL D., Zdráhal Z., Mikeš L. 2016: Major acid endopeptidases of the blood-feeding monogenean Eudiplozoon nipponicum (Heteronchoinea: Diplozoidae). Parasitology 143: 494-506.

JiANG N.C. 1991: [Family Diplozoidae.] In: B.H. Wu, X.D. Sun, C.C. Song (Eds), Fauna of Zhejiang. Trematoda. Zhejiang Science and Technology Publishing House, Zhejiang, 416 pp. (In Chinese.)

JiAnG N.C. 2000: Family Diplozoidae. In: B.H. Wu, S. Long, W.J. Wang (Eds). [Fauna Sinica Platyhelminth, Monogenea.] Science Press, Beijing., pp. 635-674. (In Chinese with English abstract.)

JiANG N.C., WU B.H., WANG S.X. 1989: [Studies on the trematode of subfamily Diplozoinae in China.] Acta Zool. Sin. 35: 259-269. (In Chinese.)

Jovelin R., JUstin J.L. 2001: Phylogenetic relationships within the polyopisthocotylean monogeneans (Platyhelminthes) inferred from partial 28S rDNA sequences. Int. J. Parasitol. 31: 393-401.

Kamegai S. 1968: On Diplozoon nipponicum Goto, 1891. Part II. The distribution in Japan and the developmental observation. Res. Bull. Meguro Parasitol. Mus. 2: 1-8.

Kamegai S. 1970a: On Diplozoon nipponicum Goto, 1891 Part III. The seasonal development of the reproductive organs of Diplozoon nipponicum parasitic on Cyprinus carpio. Res. Bull. Meguro Parasitol. Mus. 3: 21-25.
KAMEgai S. 1970b: An abnormal shape of reproductive organs of Diplozoon nipponicum Goto, 1891 from an old carp at Lake Kasumigaura. Res. Bull. Meguro Parasitol. Mus. 4: 20.

Kamegai S. 1973: [On the clamps of Diplozoon nipponicum.] Jpn. J. Parasitol. (Suppl. 22): 98. (In Japanese.)

Kamegai S. 1974a: [Studies on the genus Diplozoon. Additional new locality of D. nipponicum.] Jpn. J. Parasitol. (Suppl. 23): 89. (In Japanese.)

Kamegai S. 1974b: Studies on Diplozoon nipponicum Goto, 1891. In: Abstracts of ICOPA III, Munich, Germany, pp. 334-335.

Kamegai S. 1975a: [Survey of Diplozoon from fishes in Lake Biwa]. Jpn. J. Parasitol. (Suppl. 1) 24: 5. (In Japanese.)

Kamegai S. 1975b: [Studies on the genus Diplozoon. On Diplozoon nipponicum from crucian carps in Lake Onuma, Hokkaido.] Jpn. J. Parasitol. (Suppl. 24): 68. (In Japanese.)

Kamegai S. 1976: [Studies on Diplozoon Nordmann, 1832.] Jap. Soc. Syst. Zool. Circular 49: 1-9. (In Japanese.)

Kamegai S. 1977: [Study on the genus Diplozoon. Survey of crucian carps and common carps in the Tama River, Tokyo.] Jpn. J. Parasitol. (Suppl. 26): 45. (In Japanese.)

Kamegai S. 1986: [Study on the genus Diplozoon. The first record of Diplozoon from South Korea.] Jpn. J. Parasitol. (Suppl. 1) 35: 15. (In Japanese.)

Kamegai S., Ichihara A., Kato K., Nonobe H. 1966: [Study on Diplozoon nipponicum Goto, 1891. Part 1. Morphological observation on the worms obtained from Cyprinus carpio.] Month. Rep. Meguro Parasitol. Mus. 83/84: 2-9. (In Japanese.)

Kamegai S., Ichihara A., Kato K., Nonobe H., Machida M. 1965: [On a few parasite species obtained from fishes in Lake Kasumigaura: about the eggs of Diplozoon nipponicum from carps and Digramma alterans from Sarcocheilichthys variegatus.] Jpn. J. Parasitol. 14: 607-608. (In Japanese.)

KaWATSU H. 1978: Studies on the anemia of fish - IX. Hypochromic microcytic anemia of crucian carp caused by infestation with a trematode, Diplozoon nipponicum. Bull. Jap. Soc. Sci. Fish. 44: $1315-1319$.

Khotenovsky I.A. 1981: [Taxonomy and phylogeny of monogeneans of the families Diplozoidae and Discocotilidae (Monogenea).] Parazitologiya 30: 166-178. (In Russian with English abstract.)

KHoteNOVSKy I.A. 1985: [Fauna of the USSR, Monogenea.] USSR Academy of Sciences, Zoological Institute, New Series. 132: 215-218. (In Russian.)

Kimura M. 1977: [Study of Diplozoon nipponicum Goto, 1891: effects of water temperature and medium on adult worm culture.] Meguro Parasitol. Mus.News 128: 5-14. (In Japanese.)

Kitahara T., Hirose H., Hibiya T. 1986: [Histological observation on the reproductive organs of Diplozoon nipponicum during non-spawning period.] Bull. Jap. Soc. Sci. Fish. 52: 1307-1312. (In Japanese with English abstract.)

Koнashi K. 1994: [Identification of 3 subspecies of Carrasius fries in Lake Biwa.] Annual Reports of Shiga Prefectural Fisheries Experiment Station, 1993-1994 fiscal year. pp. 49-50. (In Japanese.)

Kohlmann K., Kersten, P. 2013: Deeper insight into the origin and spread of European common carp (Cyprinus carpio carpio) based on mitochondrial D-loop sequence polymorphisms. Aquaculture 376-379: 97-104

Konstanzová V. 2017: Ultrastructural studies on diplozoid species (Diplozoidae, Monogenea) - an analysis of selected organ systems. PhD dissertation. Department of Botany and Zoology, Faculty of Science, Masaryk University, $135 \mathrm{pp}$.

Konstanzová V., KoubKová B., KašnÝ M, Ilgová J., Dzika E., Gelnar M. 2016: Excretory system of representatives from family Diplozoidae (Monogenea). Parasitol. Res. 115: 14931500.

KoRnAKOVA E.E. 1983: [Structure of the anterior part of the digestive tract of some representatives of Diplozoinae (Monogenea, Diplozoidae).] Parazitol. S. 31: 95-107. (In Russian with English abstract.) 
KošKová E., Matějusová I., Civánová K., Koubková B. 2010: Ethanol-fixed material used for both classical and molecular identification purpose: Eudiplozoon nipponicum (Monogenea: Diplozoidae) as a case of parasite species. Parasitol. Res. 107: 909-914.

Kotтelat M. 1997: European freshwater fishes. Biologia (Suppl. 5) 52: 1-271.

Koval V.P., Pashkevishute A.S. 1969: [Monogenea of the genus Diplozoon of fish in the Ukrainian rivers]. Trudy Nauch. Konf. Parazit. UkSSR (6 Volume), pp. 232-233. (in Russian)

Kumar S., Stecher G., Tamura K. 2016: MEGA7: molecular evolutionary genetics analysis version 7.0 for bigger datasets. Mol. Biol. Evol. 33: 1870-1874.

Lambert A., Denis A. 1982: Étude de l'oncomirachidium de Diplozoon nipponicum Goto, 1891: hapteur larvaire d'un type nouveau pour le genre Diplozoon (Monogenea, Discocotylidae) Annal. Parasitol. 57: 533-542.

LAmbert A., Le Brun, N. 1988: Hypothèse sur l'origine biogéographique de Diplozoon (Monogenea, Polyopisthocotylea). Annal. Parasitol. Hum. Comp. 63: 99-102.

Le Brun N., Renaud F., Lambert A. 1985: Le problème de l'espèce chez Platyhelminthes, Monogenea, Polypisthocotylea. Bull. Soc. Franç. Parasitol. 1: 105-109.

Le Brun N., Renaud F., Lambert A. 1988: The genus Diplozoon (Monogenea, Polypisthocotylea) in southern France: speciation and specificity. Int. J. Parasitol. 18: 395-400.

Littlewood D.T.J., Olson P.D. 2001: Small subunit rDNA and the Platyhelminthes: signal, noise, conflict and compromise. In: D.T.J. Littlewood, R.A. Bray (Eds). Interrelationships of the Platyhelminthes. Chapter 25. Taylor \& Francis, London, pp. 262-278.

Littlewood D.T.J., Rohde K., Clough K.A. 1997: Parasite speciation within or between host species? Phylogenetic evidence from site-specific polystome monogeneans. Int. J. .Parasitol. 27: 1289-1297.

Lü H.C., YANG L.H., FANG X.T. 1996: [Preliminary study on fish parasites in Hulun Hu Lake.] Chin. J. Zool. 31: 49 (In Chinese.)

Lumme J., Ziętara M.S., Lebedeva D. 2017: Ancient and modern genome shuffling: reticulate mito-nuclear phylogeny of four related allopatric species of Gyrodactylus von Nordmann, 1832 (Monogenea: Gyrodactylidae), ectoparasites on the Eurasian minnow Phoxinus phoxinus (L.) (Cyprinidae). Syst. Parasitol. 94: $183-200$

Mabuchi K., Nishida M. 2006: PCR-based single tube genotyping of mitochondrial DNA of Lake Biwa wild common carp. Fish Genetics and Breeding Science 35: 19-23. (In Japanese.)

Mabuchi K., Senou H., Nishida M. 2008: Mitochondrial DNA analysis reveals cryptic large-scale invasion of non-native genotypes of common carp (Cyprinus carpio) in Japan. Mol. Ecol. 17: 796-809.

Mabuchi K., Senou H., Suzuki T., Nishida M. 2005: Discovery of an ancient lineage of Cyprinus carpio from Lake Biwa, central Japan, based on mtDNA sequence data, with reference to possible multiple origins of koi. J. Fish Biol. 66: 1516-1528.

Mabuchi K., Senou H., Takeshima H., Nakai K., NishidaM. 2010. Distribution of native Japanese mtDNA haplotypes of the common carp (Cyprinus carpio) in Lake Biwa. Jpn. J. Ichthyol. 57: 1-12. (In Japanese with English abstract.)

Matejusová, I., Koubková B., Cunningham C.O. 2004: Identification of European diplozoids (Monogenea, Diplozoinae) by restriction digestion of the ribosomal RNA internal transcribed spacer. J. Parasitol. 90: 817-822.

Matejusová, I., Koubková B., D’Amelio S., Cunningham C.O. 2001: Genetic characterization of six species of diplozoids (Monogenea; Diplozoidae). Parasitology 123: 465-474.

Mhaisen F.T. 2019: Checklists of parasites of fishes of Thi-Qar province, Iraq. Biol. Appl. Environ. Res. 3: 152-167.

Mhaisen F.T., Abdul-Ameer K.N. 2014: Checklists of diplozoid species (Monogenea) from fishes of Iraq. Bull. Iraq Nat. Hist. Mus. 13: $95-111$.
Mhaisen F.T., Abdul-Ameer K.N., Hamdan Z.K. 2018: Checklists of parasites of fishes of Salah Al-Din Province, Iraq. Biol. Appl. Environ. Res. 2: 180-218.

Mhaisen F.T., Al-Rubae A.R.L. 2016: Checklists of parasites of farm fishes of Babylon Province, Iraq. J. Parasitol. Res. 2016: 7170534

Mhaisen F.T., Al-Rubae A.R.L., Al-Sa'Adi, B.A.H. 2015: Monogenean parasites of fishes from the Euphrates river at Al-Musaib City, Mid Iraq. Am. J. Biol. Life Sci. 3: 50-57.

Miyaji D., Kawanabe H., Mizuno N. 1976: [Coloured Illustrations Freshwater Fishes of Japan]. Hoikusya, Osaka, 462 pp. (In Japanese.)

Miyamoto S., Nakajima T. 2006: [The distribution changes of Japanese freshwater fishes and human impact since the Jomon Period, using the fish remains.] Zooarchaeology 23: 39-53 (In Japanese with English abstract.)

Mizuo H., Imashita M., Saito H., Nakajima S., Hirose H., Ogawa K., Higuchi F., Fukushima S. 1999: [Helminth fauna of fishes in the rivers of Yokohama City]. Reports of the Environmental Planning Bureau, Yokohama, 23: 46-50. (In Japanese.)

Molodozhnikova N.M., Zhокноv A.E. 2006: [Taxonomic diversity of parasites from agnathans and fishes in the Volga basin. II. Parasitic Coelenterata and Monogenea.] Parazitologiia 40: 328-354. (In Russian.)

Nagasawa K. 2016: A note on Eudiplozoon nipponicum and Diplozoon sp. (Monogenea: Diplozoidae) parasitic on cyprinids in Japan, with a list of the works of Dr. Satoru Kamegai on diplozoids. Graduate School of Biosphere Science, Hiroshima Univ. Japan 55: 39-56. (In Japanese with English abstract.)

NaGasawa K., Awakura T., Urawa S. 1989: A checklist and bibliography of parasites of freshwater fishes of Hokkaido. Sci. Rep. Hokkaido Fish Hatch. 44: 1-49.

NaKabo T. (ED.) 2013: [Fish Species of Japan with Pictorial Keys to the Species. Third Edition.] Tokai University Press, Hiratsuka, 2350 pp. (In Japanese.)

NedeVA I. 1991: New data about species composition on monogeneans: Diplozoidae Palombi, 1949 in Bulgaria. Khelminthologiya 30: 27-38.

OGanessyan R.L. 2004: [Helminthological estimation of the Ponder carp farms in the Ararat plain.] Parazitologiya 38: 88-93. (In Russian with English abstract.)

Oganessyan R.L. 2009: [New species in helmintofauna of fish in Armenia.] Biol. J. Armenia 3: 32-37. (In Russian.)

OGaWA K. 1994: Monogenean parasites of freshwater fishes of Hokkaido, Japan. Sci. Rep. Hokkaido Fish Hatch. 48: 59-67.

Ogawa K. 2010-2011. Monogenea. In: O.A. Timoshkin et al. (Eds), Index of animal species inhabiting Lake Baikal and its catchment area, Vol II. Basins and channels in the south of east Siberia and North Mongolia. Book 2. Chapter 3.4. Nauka, Novosibirsk, pp. 1463-1464.

Olson P.D., Littlewood D.T. 2002: Phylogenetics of the Monogenea - evidence from a medley of molecules. Int. J. Parasitol. 32: $233-244$.

OndračKová M., Valová Z., Kortan J., Vojtek L., Adámek Z. 2012: Consequent effects of the great cormorant (Phalacrocorax carbo sinensis) predation on parasite infection and body condition of common carp (Cyprinus carpio). Parasitol. Res. 110: 1487-1493.

OsmanOv S.O. 1971: [Parasites of Uzbekistan]. FAN, Tashkent, 530 pp. (In Russian.)

Pojmańska T., Chabros M. 1993: Parasites of common carp and three introduced cyprinid fish in pond culture. Acta Parasitol. 38: 101-108.

Pugachev O.N., Gerasev P.I., Gussev A.V., Ergens R., KhoTENOWSKY I.A. 2010: Guide to Monogenoidea of Freshwater Fish of Palaearctic and Amur Regions. Ledizione-LediPublishing, Milan, $562 \mathrm{pp}$.

Reichenbach-Klinke H.H. 1961: Die Gattung Diplozoon v. Nordmann. Zugleich Neubeschreibung einer species und Zwei- 
er Subspecies sowie Revision der Gattung. Z. Parasitenkd. 20: 541-557.

Rhee J.K. 1985: A record of Diplozoon nipponicum Goto, 1891 found from Cyprinus carpio nudus in Korea. Kor. J. Parasitol. 23: 331-333.

Rohlenová K., Morand S., Hyršl P., Tolarová S., FlajšHans M., ŠımkovÁ A. 2011: Are fish immune systems really affected by parasites? An immunoecological study of common carp (Cyprinus carpio). Parasit. Vectors 4: 120.

Roudnický P., Vorel J., Ilgová J., Benovics M., Norek A., JedličKová L., Mikeš L., PotěŠIl D., ZdRÁhal Z., DvořáK J., Gelnar M., KAŠNÝ M. 2018: Identification and partial characterization of a novel serpin from Eudiplozoon nipponicum (Monogenea, Polyopisthocotylea). Parasite 25: 61.

Samman A. 1989: Incidence of monogenean species on the gills of common carp (Cyprinus carpio) collected from Hungarian and Syrian fish farms. Parasitol. Hung. 22: 45-50.

Schabussova I., Koubková B., Gelnar M., Schabuss M., HoráK, P. 2004: Surface carbohydrates of Eudiplozoon nipponicum pre- and post-fusion. J. Helminthol. 78: 63-68.

ShimazU T., Araki J. 2006: A list of helminth parasite specimens deposited in the Department of Zoology, the University Museum, the University of Tokyo. In: R. Ueshima (Ed.), Catalogue od Invertebrate Collection Deposited in the Department of Zoology, the University Museum, the University of Tokyo. The University Museum, Tokyo, pp. 151-161.

Shimazu T., Kobayashi K., Tojo K., Besprozvannykh V.V., Ogawa K. 2015: Paradiplozoon skrjabini (Monogenea, Diplozoidae), an ectoparasite on the gills of freshwater fishes (Cyprinidae, Leuciscinae) of Japan and Primorsky Region, Russia: a morphological and molecular study. Bul. Natl. Mus. Nat. Sci. Ser. A. 41: 137-154.

Sicard M., Desmarais E., Lambert A. 2001: Caractérisation moléculaire des populations de Diplozoidae sur cinq espèces de Cyprinidae: nouvelles données sur la spécificité parasitaire. Life Sci. 324: 709-717. (In French.)

Sicard M., Desmarais E., Lambert A. 2002: Is the Octomacridae the sister family of the Diplozoidae? Parasite 9: 85-87.

Sicard M., Desmarais E., Vigneux F., Shimazu T., Lambert A. 2003: Molecular phylogeny of the Diplozoidae (Monogenea, Polyopisthocotylea) parasitising 12 species of Cyprinidae (Teleostei): new data about speciation. In: C. Combes and J. Jourdane (Eds), Taxonomy, Ecology and Evolution of Metazoan Parasites. Presses Universitaires de Perpignan, Perpignan, pp. 199-211.

Šimková A., DÁvidová M., PAPOUŠEk I., VeteŠník L. 2013: Does interspecies hybridization affect the host specificity of parasites in cyprinid fish? Parasit. Vectors 6: 95.

Šmiga L., Košuthová L., Košuth P., Koščo J., Lazar, P. 2016 Parasite diversity of common carp (Cyprinus carpio L.) from aquaculture systems in eastern Slovakia. Folia Vet. 59: 169-172.

Stojanovski S., Hristovski N., Cakic P., Cvetkovic A., Atanassov, G., Smiljkov, S. 2008: Fauna of monogenean trematodes - parasites of cyprinid fish from Lake Dojran (Macedonia). Nat. Montenegr. 7: 389-398.

Strelkov J.A. 1971: [Monogenic trematodes from the fishes of the River Amur's basin.] In: Parazitol. sb. 30: 40-76. (In Russian.)
Svobodová Z., Vykusová, B., Kauer V., Svoboda, M., ŠedivÝ D., Votípka, p. 1990: [Effectiveness of some therapeutic baths to control of carp invasion by Eudiplozoon nipponicum. Buletin VÚRH Vodňany, Vodňany, pp. 3-13.] (In Czech.)

SzÉKely C., MolnáR K. 1998: Preliminary survey of the parasite fauna of some important fish species in the Upper-Reservoir of the Kis-Balaton system. Parasitol. Hung. 29-30: 45-54.

Tavakol S., Halajian A., Dos Santos Q.M., Luus-Powell W., Yeganeh A. 2013: Monogeneans of Cyprinidae in Iran. Review with new record of Eudiplozoon nipponicum from Cyprinus carpio. Abstract of $7^{\text {th }}$ International Symposium on Monogenea. Riode Janeiro, Brazil., pp. 92

Valigurová A., Hodová I., Sonnek R., Koubková B., Gelnar M. 2011: Eudiplozoon nipponicum in focus: monogenean exhibiting a highly specialized adaptation for ectoparasitic lifestyle. Parasitol. Res. 108: 383-394.

WAN X., Yue C. 2015: Study on classification, population ecology and molecular systematics of diplozoid in Ergis River. Basic knowledge of Xinjiang Agricultural University, Prevention of Veterinary Medicine, Master thesis.

Xu J., Jiang, Y., ZhaO, Z., Zhang H., Peng W., Feng J., Dong C., Chen B., TAI, R., XU, P. 2019: Patterns of geographical and potential adaptive divergence in the genome of the common carp (Cyprinus carpio). Front. Genet. 10: 660.

Yamaguti S. 1963: Systema Helminthum. Vol. IV, Monogenea and Aspidocotylea. John Wiley \& Sons, London, 699 pp. + 134 Plts.

Yin W.Y., Sproston N.G. 1948: A note on Diplozoon nipponicum Goto, from the goldfish. Sinensia 19: 82-85.

Zhang D., Zou H., Wu S.G., Li M., Jakovlic I., Zhang J., Chen R., Li W.X. Wang, G.T. 2018: Three new Diplozoidae mitogenomes expose unusual compositional biases within the Monogenea class: implications for phylogenetic studies. BMC Evol. Biol. 18: 133.

Zhang X.L., Jiao L., Hao C.L., Wang B.L., Jia S.A., Yue C. 2012: Species composition and parasitic characteristics of parasites of Cyprinus carpio Linnaeus in Ergis River. Xinjiang Agricul. Sci. 49: 576-580.

Ziętara M.S., Rokicka M., Stojanovski S., Lumme, J. 2010: Introgression of distant mitochondria into the genome of Gyrodactylus salaris: nuclear and mitochondrial markers are necessary to identify parasite strains. Acta Parasitol. 55: 20-28.

Zurawski T.H., Mair G.R., Maule, A.G., Gelnar, M., HalTON, D.W. 2003a: Microscopical evaluation of neural connectivity between paired stages of Eudiplozoon nipponicum (Monogenea: Diplozoidae). J. Parasitol. 89: 198-200.

Zurawski T.H., Mousley A., Mair G.R., Brennan G.P., Maule A.G., Gelnar M., Halton D.W. 2001: Immunomicroscopical observations on the nervous system of adult Eudiplozoon nipponicum (Monogenea: Diplozoidae). Int. J. Parasitol. 31: 783-792.

Zurawski T. H., Mousley A., Maule A.G., Gelnar M., HalTON D. W. 2003b: Cytochemical studies of the neuromuscular systems of the diporpa and juvenile stages of Eudiplozoon nipponicum (Monogenea: Diplozoidae). Parasitology 126: 349-357.

Cite this article as: Nishihira T. and Urabe M. 2020: Morphological and molecular studies of Eudiplozoon nipponicum and Eudiplozoon kamegaii sp. n. (Monogenea; Diplozoidae). Folia Parasitol. 67: 018. 